\title{
An evaluation and implementation of the regional coupled ice-ocean model of the Baltic Sea
}

\author{
Jaromir Jakacki ${ }^{1}$ (D) . Sebastian Meler ${ }^{1}$ \\ Received: 10 December 2017 / Accepted: 20 August 2018 / Published online: 2 October 2018 \\ (C) The Author(s) 2018
}

\begin{abstract}
A three-dimensional, regional coupled ice-ocean model based on the open-source Community Earth System Model has been developed and implemented for the Baltic Sea. The model consists of 66 vertical levels and has a horizontal resolution of approx. $2.3 \mathrm{~km}$. The paper focuses on sea ice component results, but the main changes have been introduced in the ocean part of the coupled model. The hydrodynamic part, being one of the most important components, has been also presented and validated. The ice model results were validated against the Synthetic Aperture Radar (SAR) and satellite data, and the method of validation based on probability was introduced. In the last two decades, satellite and model results show an increase in the ice extent over the whole Baltic Sea, which is an evidence of a negative trend in air temperature in recent decades and increasing of winter discharge from the catchment area.
\end{abstract}

Keywords Modeling $\cdot$ Baltic Sea $\cdot$ Ice cover $\cdot$ Coupled models $\cdot$ Regional models $\cdot$ Hydrodynamic modeling

\section{Introduction}

In the Baltic Sea, coupled ice-ocean models have been developed and used for more than two decades, whereas coupled land-atmosphere-sea models-for about 15 years BACC and BACC II (Omstedt et al. 2004, 2014). First high-resolution fully coupled atmosphere-sea-ice-oceanland-surface models (Döscher et al. 2002; Gustafsson et al. 1998; Hagedorn et al. 2000; Schrum et al. 2003) were built during BALTEX Phase I. The models were developed to improve short-range weather forecast. In the beginning of BALTEX Phase II, two fully coupled atmosphere-sea-iceocean models were also available (Döscher et al. 2002; Lehmann et al. 2004). Now, other groups are developing their own models (e.g., Dieterich et al. 2013; Pham et al. 2014; Tian et al. 2013 of the Baltic Sea region. The second phase of BALTEX focused more on studying climate change. Coupled atmosphere-sea-ice-ocean models were further elaborated using a hierarchy of sub-models of the earth system combining RCMs (Regional Climate Models)

Responsible Editor: Sandro Carniel

Jaromir Jakacki

jjakacki@iopan.pl

1 Institute of Oceanology of Polish Academy of Sciences, Sopot, Poland with sub-models of surface waves (Almroth-Rosell et al. 2011; Rutgersson et al. 2012)), land vegetation (Smith et al. 2011), hydrology and land biochemistry (Arheimer et al. 2012; Mörth et al. 2007), marine biogeochemistry (Daewel and Schrum 2013; Eilola et al. 2009, 2011; Neumann et al. 2002; Savchuk et al. 2012), the marine carbon cycle (Edman and Omstedt 2013; Gustafsson et al. 2014; Kuznetsov and Neumann 2013; Omstedt et al. 2010), marine biology (Hense et al. 2013; Meier et al. 2011), and food web modeling (MacKenzie et al. 2012; Niiranen et al. 2013) as well as with socioeconomic impact assessments (Piwowarczyk et al. 2012). The Gulf of Finland was simulated using a horizontal resolution of 0.25 nautical miles (Andrejev et al. 2010). Gräwe et al. (2013) studied saltwater inflows in the future climate using a model of the western Baltic Sea with a horizontal resolution of less than $1 \mathrm{~km}$. River inflows are represented by large-scale HBV hydrological model (Lindström et al. 1997) of the entire Baltic catchment area (Graham 1999, 2004). Later, two new hydrological models have been developed to calculate future river flows and river-borne nutrient loadings, i.e., the Hydrological Predictions for the Environment (HYPE) model (Arheimer et al. 2012; Lindström et al. 2010) and the Catchment Simulation Model (CSIM, Mörth et al. 2007). As meteorological forcing, high-resolution Baltic Sea simulations typically use the output of local atmosphere models, such as different versions of the High Resolution 
Limited Area Model (HIRLAM) (www.hirlam.org) or the Deutscher Wetterdienst (DWD) model (www.dwd.de), or ERA-40 reanalysis data (Uppala et al. 2005) or their downscalings (Höglund et al. 2009; Samuelsson et al. 2011).

In this work, the recently developed Community Earth System Model (CESM, Hurrell et al. 2013) has been used and implemented for the whole Baltic Sea. CESM is a descendant of the Community Climate Model (CCM, Williamson et al. 1987; Hack et al. 1993), the Climate System Model (CSM), and the Community Climate System Model (CCSM version 3, (Blackmon et al. 2001)) developed by the National Centre for Atmospheric Research (NCAR). Up to the mid-1990s, the CCM was of limited use as a climate model because it did not include sub-models of the global ocean and sea ice.

The first plan to develop and use a climate system model (CSM), including the atmosphere, land surface, ocean, and sea ice was proposed to the National Science Foundation (NSF) in 1994 (Blackmon et al. 2001). The recent releases were also improved by the University Centre for Atmospheric Research (UCAR). The latest CCSM version 4 consists of four separate components, atmosphere (atm), ocean (ocn), sea-ice (ice), and land (lnd), coupled by a central coupler component. The main difference between current version of CCSM and CESM is that new biogeochemistry capabilities were added in the CESM model. It means that CESM is only a newer version of CCSM. It is also important that CESM includes CCSMit is possible to run simulations implemented in CCSM using CESM model. CESM has a set of configurations, and selected ones have been already scientifically validated. All configurations are based on global grids, except the RACM/RASM project (Regional Arctic Climate/ System Model) that develops all active components in a coupled, regional Pan-Arctic climate model (Maslowski et al. 2009, 2012; Cassano et al. 2010). Since resolutions of the provided configurations are not suitable for the Baltic Sea, one of challenges in the presented implementation was to adequately increase both horizontal and vertical resolution.

For the purpose of this study, the CESM was adopted for the Baltic Sea. The implemented version includes two active components, ocean (Parallel Ocean Program, POP) and ice (Community Ice CodE, CICE), and two data models representing atmosphere (datm) and land (dlnd). The active (dynamical) components are fully prognostic models, whereas the basic function of data models is reading external data (interpolated outside of the model), modifying that data and sending them to the central coupler. The central coupler (cpl7) is responsible for the coordination and the flow of information between all components. The coupler and other models have no fundamental knowledge of whether another component is fully active or just a data model. The implemented setup of the Baltic Sea model is

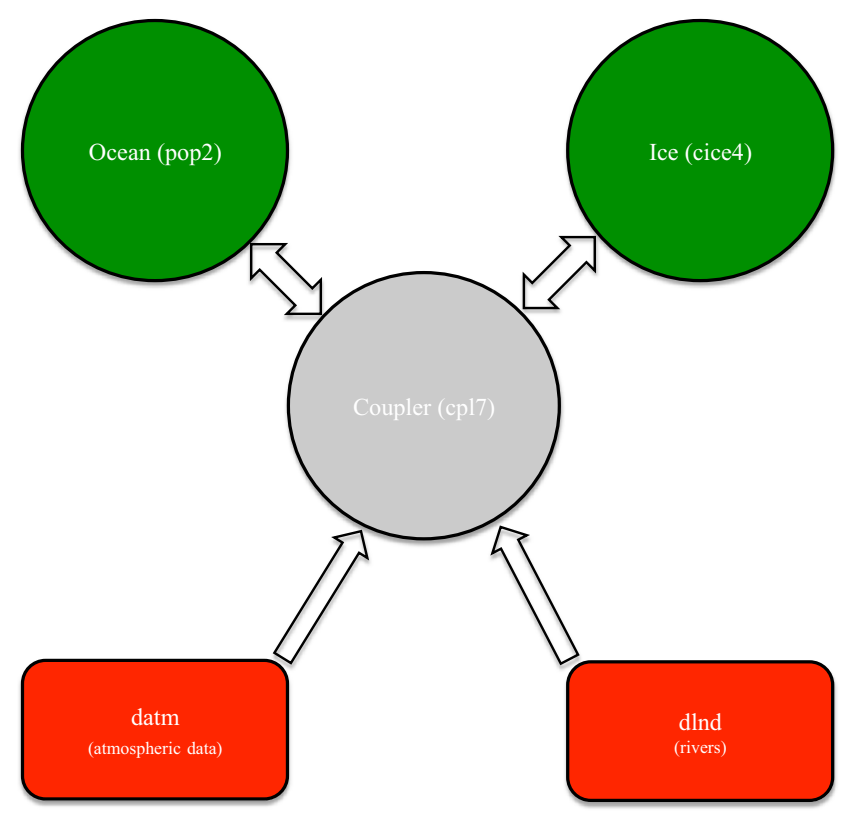

Fig. 1 The Baltic Sea coupled model diagram

shown in Fig. 1. We call this model B-CESM and currently it works in operational mode (Jakacki et al. 2017).

In the above configuration, different data sets have been used as external forcings. The river runoff data from the Baltic HYdrological Predictions for the Environment model (Balt-Hype, Lindström et al. 2010), covering the years 1971-2008 were provided by the Swedish Meteorological and Hydrological Institute (SMHI). The river runoff climatology was calculated from available period and employed in the model for missing period. Based on climatology, the simulation was extended to 2012. In total, data for 75 rivers have been implemented in the model. Two major methods are commonly used for implementing the river runoff data in ocean models. The most often applied approach is to treat a river runoff as precipitation, which changes salinity of the uppermost cells. Another way is to add the freshwater input as precipitation but instead salinity change, the freshwater volume is added to the model upper cells. This requires removal of the additional water volume at the lateral boundary of a regional model as was done in the presented Baltic Sea model. Our approach is nonstandard and has been implemented only for the purpose of this model for the Vistula River (Majewski 2015). A special channel has been added to the model domain and precipitation has been released only within this channel. The sea level difference between the channel and the Gulf of Gdansk assured velocity of the freshwater flow, which could not be obtained, if the river runoff was implemented as precipitation over the sea. The implemented channel approach gives much better results for large rivers, such as Vistula or Lena, while for smaller rivers including the river runoff as precipitation is commonly used. 
The presented results were obtained with the Baltic Sea model using atmospheric forcing from ERA Interim reanalysis (ERAi, ECMWF, 1979-present, $0.75^{\circ}$ horizontal resolution, Berrisford et al. 2011) and data from the local forecast model UM run by the Interdisciplinary Modeling Centre at the University of Warsaw (ICM, approx. $4 \mathrm{~km}$ horizontal resolution, 2010-2014). Atmospheric forcing variables required by the model includes the following:

- Temperature at $2 \mathrm{~m}$

- Specific humidity at $2 \mathrm{~m}$

- Wind speed and direction at $10 \mathrm{~m}$

- Mean sea level pressure

- Short and long wave radiation downward

- Total snow and rain precipitation

The availability of global atmospheric reanalyses permits to use them from different data sources. For example, in the case of NCEP (National Centers for Environmental Prediction, Kalnay et al. 1996; Saha et al. 2010), JMA (Japan Meteorological Agency, Onogi et al. 2007), NASA (National Aeronautics and Space Administration, Rienecker et al. 2011; Schubert et al. 1993), and ECMWF (Dee et al. 2011; Berrisford et al. 2011), it is possible to use data that cover the Baltic Sea area and all of them have resolution lower then $1^{\circ}$. Also, regional analysis made by High Resolution Limited Area Model (HIRLAM) are provided with a $22 \mathrm{~km}$ horizontal resolution. This reanalysis has been done using ERAi data as boundary conditions. In our case, we use ERAi because it covers time of integration (which is limited by observational sea level data for Goteborg station) and runoff data are available for the same period. Also, data from ECMWF could be used in the Baltic Sea modeling with reasonable accuracy (Omstedt et al. 2005).

All models (components) are governed by the central coupler (cpl7), based on the Model Coupling Toolkit (MCT). It controls the exchange of data between the individual models and all time steps. The coupling time step for all models has been set to $600 \mathrm{~s}$, and the same value was also used as the ice model time step. The ocean model has its own system that controls its time steps, which are not uniform. The requested time step of the ocean model has been equal to $150 \mathrm{~s}$, and we can assume that it has been the longest step of the POP.

\section{Ocean model description and adaptation to the Baltic Sea}

The ocean component of the Baltic Sea model in the presented configuration is the Parallel Ocean Program, a well-known, three-dimensional, $z$-coordinate general circulation model (Smith and Gent 2004). The model uses hydrostatic and Boussinesq approximations for the primitive equations of the fluid motion on the orthogonal spherical grid. A free surface is implemented as pressure at the top boundary layer. A detailed description of the POP model and improvements can be found in numerous papers, e.g., Bryan (1969), Semtner (1974a, b), Cox and Laboratory, Geophysical Fluid Dynamics (1984), Killworth et al. (1991), and Mintz and Semtner (1977).

\subsection{Initial state of the model}

Both active models (ice and ocean) adopt a rotated spherical grid with horizontal resolution of $1 / 48^{\circ}$ (approx. $2.3 \mathrm{~km}$ ). To obtain the same size of all cells in a horizontal plane, the equator of the grid is located in the center of the domain. The model bathymetry is based on the ETOPO1 (Earth Topography Digital Dataset), a global 1 arc-minute relief model of the Earth's surface (Amante and Eakins 2009). The B-CESM has 66 vertical levels, of which the first 50 levels are $5 \mathrm{~m}$ thick, whereas thickness increases in deeper layers. The number of levels has been chosen to optimize the computational cost in the model, at the same time covering most of the Baltic Sea with identical cells. The compromise resulted in 66 vertical levels shown in Fig. 2 together with the model domain and bathymetry (colors represent vertical levels, detailed values of all vertical levels are presented in Table 1).

Initial conditions have been determined based on data provided by Copernicus Marine Environment Monitoring Service (CMEMS, http://marine.copernicus.eu), a global monitoring and analyzing european service. For the purpose of this model, physical reanalysis, included 3D-var data assimilation, based on High Resolution Model of the Baltic Sea (HIROMB) model has been applied. Swedish Meteorological and Hydrological Institute (SMHI) has been doing the reanalysis.

Initial temperature and salinity fields for January 1990 were interpolated over the model domain. The model started from no-motion state, which is also called a "cold start." The model was spun up for 3 years (1990-1992), and then the main simulations has begun on January 1st of 1990 . In the Baltic Sea, strong autumn storms drive very deep turbulent mixing; therefore, 3 years seems enough for the ocean model spin up. In case of ice cover or heat balance, memory is closed to 1 year. The salinity memory of the Baltic Sea is over 30 years (Omstedt and Hansson 2006). But in case of given observed (or reanalyzed) salinity, could be realistically modeled for the whole Baltic Sea.

\subsection{Lateral boundary conditions and their verification}

Although the Baltic Sea is a semi-enclosed sea, a strong salinity difference between the North Sea and the Baltic 
Fig. 2 Model domain, bathymetry (color scale in model levels) and vertical resolution (insert). The red letters refer to Baltic Sea sub-basins (BB, Bothnian Bay; BS, Bothnian Sea; GF, Gulf of Finland; GR, Gulf of Riga; BP, Baltic Proper); and KT, Kattegat

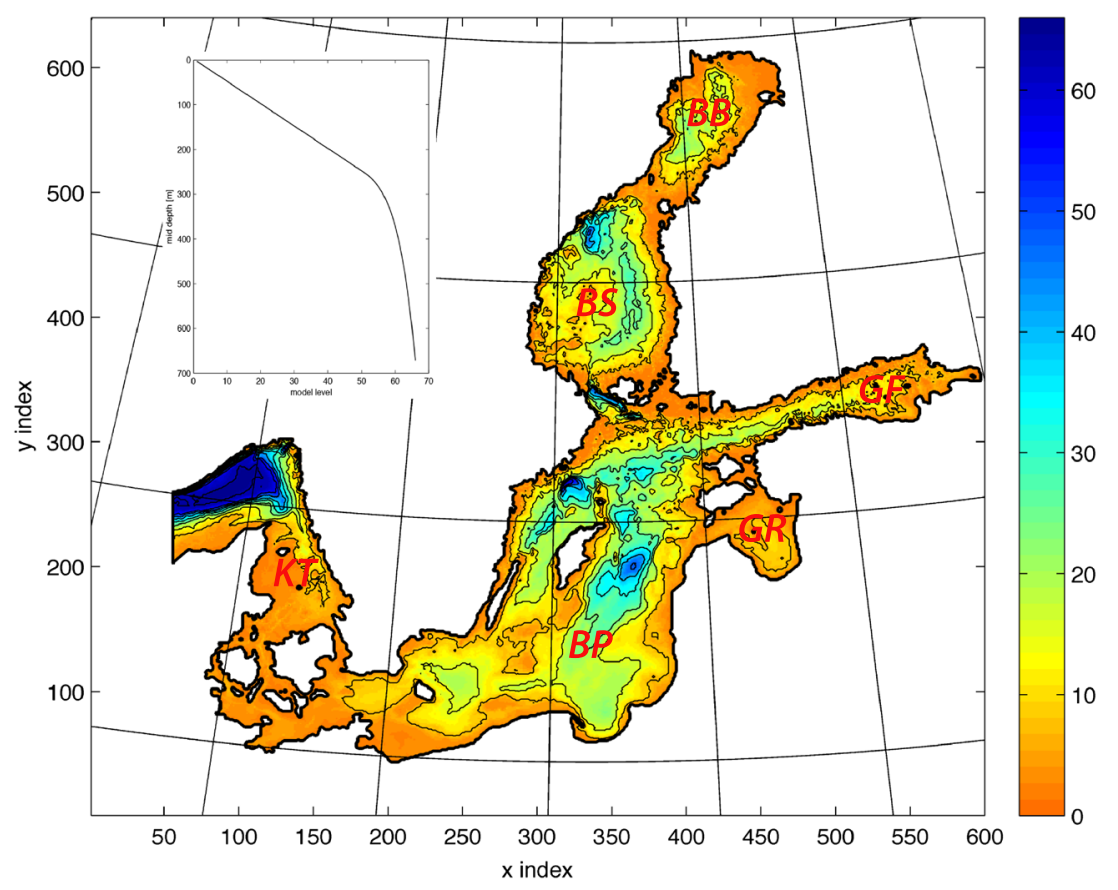

Proper results in a difference in sea level of the order of $10 \mathrm{~cm}$ between the Kattegat and the South-West Baltic. Being a transit area, the Danish Straits play the key role in water exchange between the North Sea and the Baltic Sea. Therefore, a proper implementation of boundary conditions

Table 1 Vertical resolution

\begin{tabular}{lccc}
\hline Model level & Tickness $[\mathrm{cm}]$ & Mid-depth $[\mathrm{cm}]$ & Lower depth $[\mathrm{cm}]$ \\
\hline 1 & 500 & 250 & 500 \\
2 & 500 & 750 & 1000 \\
$\ldots$ & $\ldots$ & $\ldots$ & $\ldots$ \\
50 & 500 & 24750 & 25000 \\
51 & 500 & 25250 & 25500 \\
52 & 603 & 25802 & 26103 \\
53 & 728 & 26467 & 26103 \\
54 & 878 & 27270 & 27709 \\
55 & 1059 & 28239 & 28768 \\
56 & 1277 & 29407 & 30045 \\
57 & 1540 & 30815 & 31585 \\
58 & 1858 & 32514 & 33443 \\
59 & 2241 & 34564 & 35684 \\
60 & 2704 & 37036 & 38388 \\
61 & 3262 & 40019 & 41650 \\
62 & 3934 & 43617 & 45584 \\
63 & 4746 & 47957 & 50330 \\
64 & 5725 & 53193 & 56055 \\
65 & 6906 & 59508 & 62961 \\
66 & 8330 & 67126 & 71291 \\
\hline
\end{tabular}

has strong influence upon the barotropic balance between the North Sea and the Baltic Sea and also upon the salinity distribution in the Baltic Sea. Two different approaches were used to implement lateral boundary conditions:

a) Sea level measured in Göteborg was assimilated as a boundary condition in Kattegat.

b) The Orlanski open boundary conditions (OBC) were enforced at the boundary area.

Located in the narrow and shallow connection between Skagerrak and Kattegat, Göteborg provides a convenient point for applying boundary conditions. Moreover, sea level data for this location are openly available for over 20 years (1990-today). To apply sea level assimilation for the Göteborg area, it has been necessary to introduce a modification in the barotropic equation, originally formulated as follows (Dukowicz and Smith 1994):

$\left\{\begin{array}{c}\partial_{t} u-f v=-g \partial_{x} \eta+G^{x} \\ \partial_{t} v+f u=-g \partial_{y} \eta+G^{y} \\ \partial_{t} \eta+\partial_{x} H u+\partial_{y} H v=q_{w}\end{array}\right.$

where $H$ is the total depth, $f$ is the Coriolis parameter, $(u, v)$ are the barotropic (vertically averaged) velocities, $g$ is the gravity acceleration, $G^{x}$ and $G^{y}$ are external forcings, and $\eta$ is the sea level. Symbols $\partial_{t}, \partial_{x}, \partial_{y}$ represent time and space derivatives. $q_{w}$ represents fresh water sources. The RHS of Eq. 1 represents $x$ and $y$ gradient components of the surface pressure. This part of the barotropic equation has been modified to incorporate sea surface height (SSH) at the boundary area by adding the gradient of difference between the model sea level and the SSH measured in Göteborg. 
The Cressman (1959) analysis scheme, which defines the weighting function in terms of a radius of influence, is widely used for simple assimilation systems. In our case, the Hamming window $\left(w_{h}(x, y)\right)$, which is very often used in signal processing, has been used instead of the Cressman weighting function. An advantage of this approach is that the Hamming window is represented by simple harmonic function that is the basic solution of the wave equation. The modified barotropic Eq. 1 has now the form:

$\left\{\begin{array}{c}\partial_{t} u-f v=-g \partial_{x}\left(\eta+w \eta^{\prime}\right)+G^{x} \\ \partial_{t} v+f u=-g \partial_{y}\left(\eta+w \eta^{\prime}\right)+G^{y} \\ \partial_{t} \eta+\partial_{x} H u+\partial_{y} H v=q_{w}\end{array}\right.$

where $\eta^{\prime}$ is the difference between the modeled and measured sea level in Göteborg.

The Sommerfeld (1949) radiation conditions are most commonly used at the boundary. In our case, the condition at the northern boundary is formulated as follows:

$\frac{\partial \psi}{\partial t}+c \frac{\partial \psi}{\partial y}=0$

where $\psi$ is velocity, barotropic component of velocity or sea surface height at the lateral boundary in the model, and $c$ is the wave speed. Two approaches are often applied to find the $\mathrm{c}$ parameter. One takes into account the barotropic wave speed, which is constant and depends on the depth and gravitational acceleration. The second approach, introduced by Orlanski (1976), was implemented also in our model. It uses data from the previous time step to calculate phase speed, which is applied in the current time step. Taking into account the varying $c$, Eq. 3 provides a prognostic variable at the boundary (Kantha and Clayson 2000):

$\psi_{\mathrm{jM}}^{n+1}=\psi_{\mathrm{jM}}^{n}-R\left(\psi_{\mathrm{jM}}^{n}-\psi_{\mathrm{jM}-1}^{n}\right)$

where

$R=\frac{c \Delta t}{\Delta x}=-\frac{\psi_{\mathrm{jM}-1}^{n+1}-\psi_{\mathrm{jM}-1}^{n}}{\psi_{\mathrm{jM}-2}^{n}-\psi_{\mathrm{jM}-2}^{n}}$

In Eqs. 4 and 5, $n$ represents time step and jM is the northern boundary index. In the B-CESM model, Eqs. 4 and 5 have been applied in Kattegat.

Comparison of the sea level measured in Göteborg and obtained from the model after implementing the modified boundary condition is shown in Fig. 3. Even if the modeled sea level is lower than the measured one, the applied modification of the barotropic equation produces realistic sea level variability. The main reason of discrepancy in the sea level amplitude is pressure averaging, turned on in the POP model to avoid the model becoming unstable. Pressure averaging allows for longer time step in the ocean model and reasonable integration time. Also, the model has only possibility of using linear free-surface implementation, which dumps fast waves in the model and also causes lower sea surface height oscillations. The sea level variability is presented as standard deviation (std) of each signal. Also, RMSE is presented.

Because the North Sea is the source of salt in the Baltic Sea, the flow through the Danish straits is the most important driver of the salt exchange between Kattegat and the South-West Baltic. The two main straits, Sund and Langeland Belt, are the main passages for the salt transport into the Baltic (in example Lehmann et al. 2004; Mohrholz et al. 2015). The flow through Sund is mostly driven by the sea level pressure difference between the southern and northern entrances, and can be calculated from the semiempirical expression as follows:

$\Delta \eta=K_{f} \cdot Q \cdot|Q|$

where $\Delta \eta$ is the sea level difference between the ends of Sund (Skanor and Hornbaek), $K_{f}$ is specific resistance, and $Q$ is the flow through the strait.

The long-term sea level measurements are available for two stations shown in Fig. 4. Based on measurements, the specific resistance in Sund was estimated on approximately $2.03 \times 10^{-10}$. Figure 4 shows that flow rate depends on the sea level difference for the Sund. The black line represents measurements and the red points are from the model described herein. The nonlinear regression provides the modeled (B-CESM) specific resistance $K_{f}=4.05 \times$ $10^{-10}$. For comparison, GETM (Grode 2004), NB03 (the North Sea 3 NM, (Funkquist and Kleine 2007)), and BS01 (the Baltic Sea 1 NM (Funkquist and Kleine 2007)) models provide $K_{f}$ value of $3.06 \times 10^{-10}, 3.78 \times 10^{-10}$, and $12.5 \times 10^{-10}$, respectively.

The dynamical state of the Baltic Sea is the result of balance between dense and the incoming salty waters,
Fig. 3 Modeled (red) and measured (blue) sea level in Göteborg. Modeled std $=0.06$, measured std $=0.19$, RMSE $=0.02$ (root mean square error)

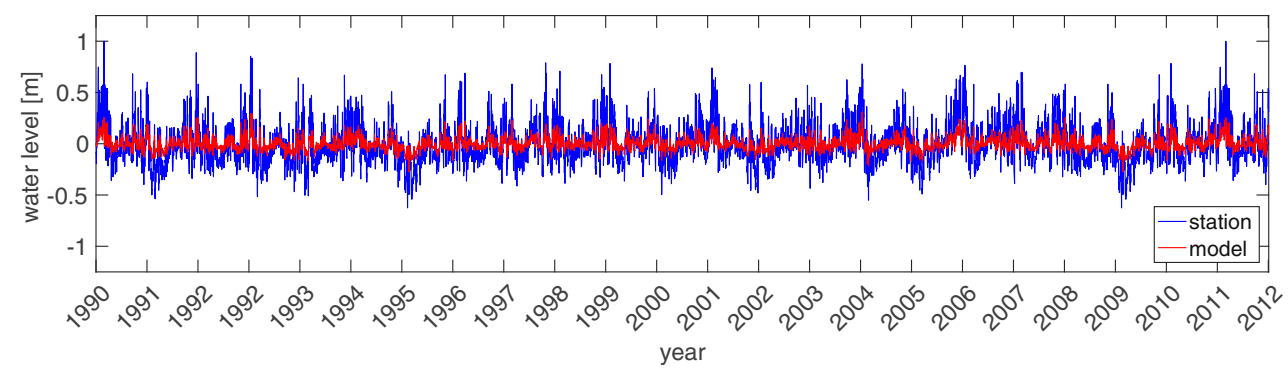


Fig. 4 Flow rate vs. sea level difference in the Sund (red points-modeled, black linecalculated from the measured sea level difference). The insert shows position of two stations at the northern and southern end of Sund and the section

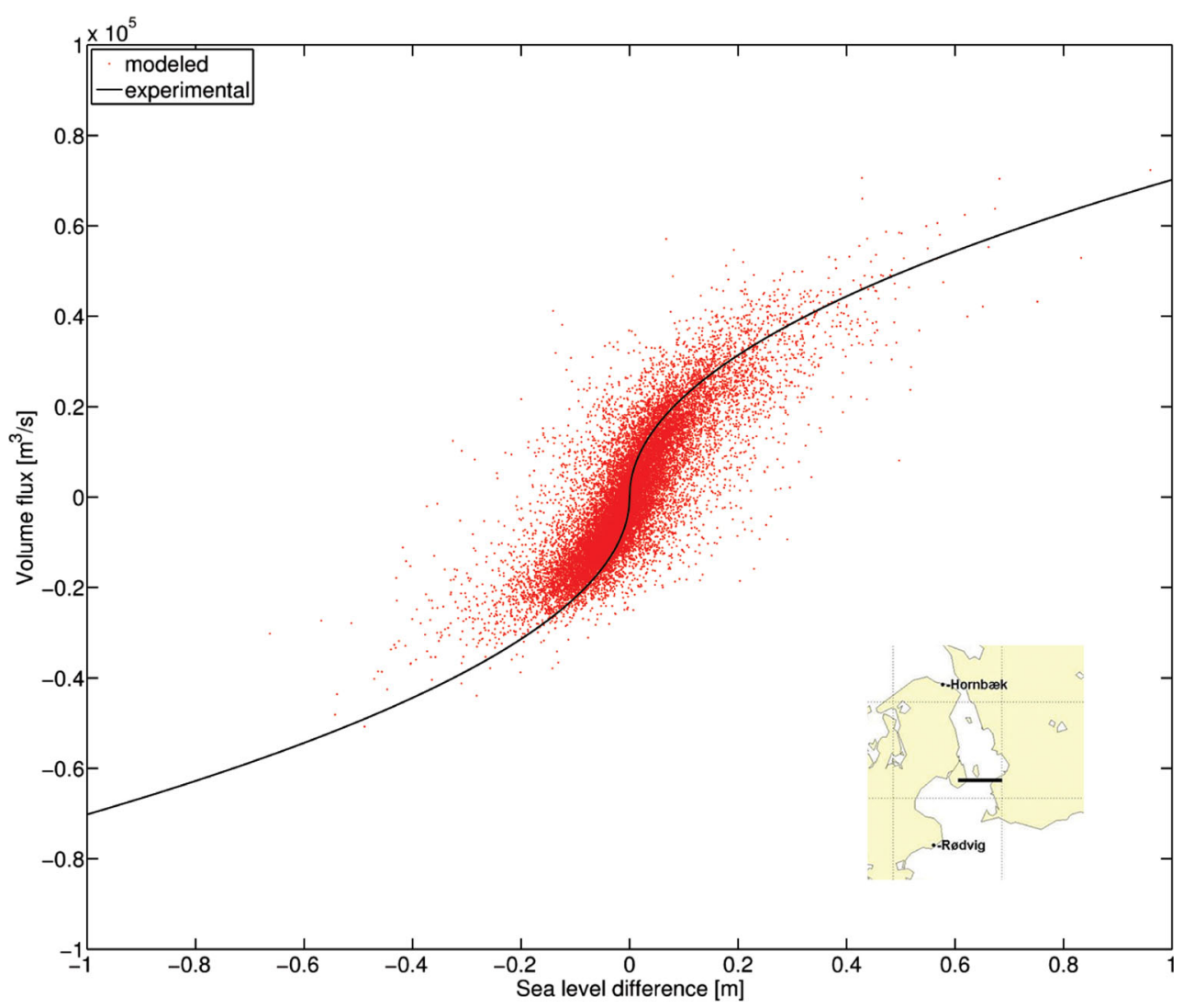

freshwater river runoff and precipitation are balanced by the mixed water outcoming through the Danish straits as well as by evaporation. Because of it, the annually averaged sea level is expected to increase from the Danish straits towards the Gulf of Bothnia. Figure 5 shows adjusted annual mean sea level at seven stations, located along the Baltic coast from west to east, obtained from three different numerical models: BS01, NB03, and GETM. BS01 and NB03 are the implementations of the HIROMB model with horizontal resolution of 1 and 3 NM respectively. GETM is a model set up by the Royal Danish Administration of Navigation and Hydrography, and in this case, it has a resolution of $1 \mathrm{NM}$ (Grode 2004).

The HIROMB models use meteorological forcing from HIRLAM (High Resolution Local Area Modelling, SMHI), while the GETM model is also driven by data obtained from HIRLAM, but from the Danish Meteorological Institute (DMI). The monitoring data were obtained from the height reference systems: Baltic HRS and Nordic Height System (NH60), which are 15 years long-time series transformed from the Swedish Height System RH70 (Carlsson 1997). Figure 5 shows the good agreement of the sea level spatial variations obtained from the presented model with HIROMB and GETM results, as well as with observations. The averaged sea level varies between the individual models because of the different atmospheric forcing (in this case, we use data from the ERA40 interim, ERA40, and Interdisciplinary Modeling Centre (ICM) at the University of Gdansk) and different resolutions. Additionally, pressure averaging in time has been implemented in the other
Fig. 5 Comparison of the adjusted annual mean sea level from three different models, observations and B-CESM

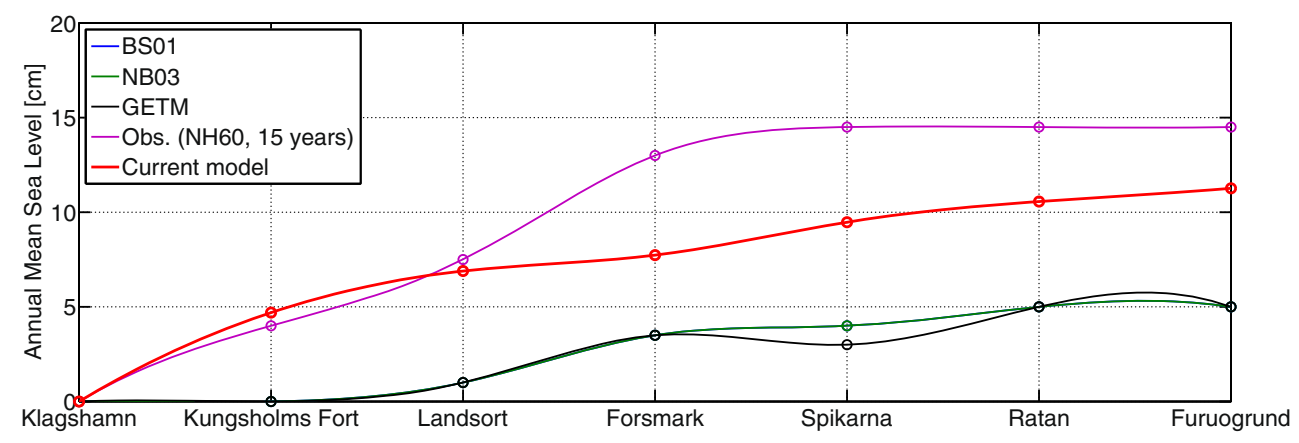


models, resulting in smaller amplitude of the sea level variations.

\subsection{Ocean model upper boundary layer}

The conservation of heat at the top layer of the open ocean model requires (Yu et al. 2007):

$Q_{\text {net }}=Q_{\text {sw }}+Q_{\text {lw }}+Q_{\text {lat }}+Q_{\text {sen }}$

where subscripts net, sw, lw, lat, and sen indicate net heat, solar short waves radiation, long-wave radiation, and latent and sensible heat flux, respectively. It has been assumed that fluxes are directed to the ocean model (the ice model will be described separately). In our model, short- and long-wave radiations are provided by datm model as external forcing (see Fig. 1). Latent and sensible heat fluxes are sent to the active components and are calculated by the central coupler based on the bulk formula:

$\left(Q_{\text {lat }}, Q_{\text {sen }}\right)=\rho_{A}|\Delta v|\left(C_{E} \Delta q, C_{p} C_{H} \Delta \theta\right)$

where $Q_{\text {lat }}$ and $Q_{\text {sen }}$ are, similar to Eq. 7, latent and sensible heat fluxes, $\rho_{A}$ is the air density, and $\Delta v$ is the velocity difference between the ocean surface and atmosphere, $\Delta q$ and $\Delta \theta$ are specific humidity and temperature differences (between the atmosphere and the ocean surface) and $\mathrm{Cp}$ is the specific heat capacity. $C_{E}$ and $C_{H}$ are transfer coefficients between the ocean surface and atmosphere (sensible heat transfer coefficient is the Stanton number, the latent heat coefficient is the Dalton number), and they depend on stability:

$C_{(E, H)}=\kappa^{2}\left[\ln \left(\frac{Z_{A}}{Z_{0 m}}\right)-\psi_{m}\right]^{-1}\left[\ln \frac{Z_{A}}{Z_{0 m}}-\psi_{h}\right]^{-1}$

where $\psi_{m}$ and $\psi_{h}$ are the integration forms of the MoninObukhov similarity functions, $Z_{A} / Z_{0 m}$ represents stability parameter, $Z_{0 m}$ is the roughness length.

Wind-natural motion of the air-always exists over the ocean. Wind blowing over the ocean surface produces tangential stress at the ocean-atmosphere interface, represented by a vertical flux of the horizontal momentum. Similar to heat fluxes, the horizontal momentum flux (wind stress $\boldsymbol{\tau}_{o}$ ) can be also described by a bulk formula:

$\tau_{o}=\rho_{A} C_{d} S\left(\mathbf{u}_{A}-\mathbf{u}_{S}\right)$

where $C_{d}$ is drag coefficient, $S$ is the wind speed relative to the ocean surface, and $\mathbf{u}_{A}$ and $\mathbf{u}_{S}$ are wind and ocean surface velocities, respectively (vector quantities indicated by italics characters).

In consequence, the vertical shear is maximal at the surface of the ocean and decreases with depth. The interaction between atmosphere and ocean produces a mixed layer, occupying the upper part of the ocean, where temperature and salinity can be approximated as constant. The mixed layer depth (MLD) depends mostly on wind speed and direction, as well as its temporal and spatial scales, and in shallow waters, also on bottom topography. An important part of the energy transfer between atmosphere and ocean upper layers is through turbulences. In the presented B-CESM model, k-profile parameterization (kpp) was used (Large et al. 1994).

The most natural turbulence model is standard $k-\varepsilon$ model (Svensson 1978; Rodi 1980). Burchard and Petersen (1999) shown that two models $k-\varepsilon$ and Mellor-Yamada level 2.5 (MY) (Mellor and Yamada 1974, 1982; Li et al. 2001) perform similarly. Due to the fact that these schemes are not available in the POP model (MY is for sigma coordinate models only), kpp has been modified to be more similar to MY based on Durski et al. (2004). The comparison of the two different schemes is not straightforward, and to obtain a similar solution to MY, the formulation of interior shear was slightly modified in kpp. The modification was introduced in the relationship between the Richardson number and the vertical viscosity coefficient. The comparison between original and modified turbulent viscosity is shown in Fig. 6. Both solutions differ in the rate at which vertical mixing decays in the presence of stratification.

\subsection{Validation of the ocean model}

Since the main focus of the current study is on the ice model, only selected results of the ocean model validation are presented in this paper. Figures 7 and 8 present the comparison of the modeled sea surface temperature with observational and satellite data from different sources. The selected locations were determined by available buoys data (presented in Fig. 7), yet, unfortunately, no valid buoy data exist for the Sodra Ostersjon. In this case, only the modeled and satellite SST data are presented (in Fig. 8, in the upper right image).

All data except the model results are incomplete. The sea temperature from surface buoys was measured at the depth of $0.5 \mathrm{~m}$. The satellite data used for comparison with the model (Fig. 8) were registered on board MODIS AQUA satellite (Moderate Resolution Imaging Spectroradiometer). The SST (Sea Surface Temperature) values were extracted from level 3 daily mosaics of $9 \mathrm{~km} \times 9 \mathrm{~km}$ spatial resolution that had been combined using a mean of values in each pixel. In order to ensure a reliable comparison, there were exploited two types of SST. The first was a heritage of the Advanced Very High Resolution Radiometer (AVHRR), and it was based on the 31st and 32nd MODIS bands (at 11 and $12 \mu \mathrm{m}$ respectively) (Kilpatrick et al. 2015). This method requires an input surface temperature 
Fig. 6 Original and modified (used in this simulations) turbulent viscosity (after Durski et al. 2004)

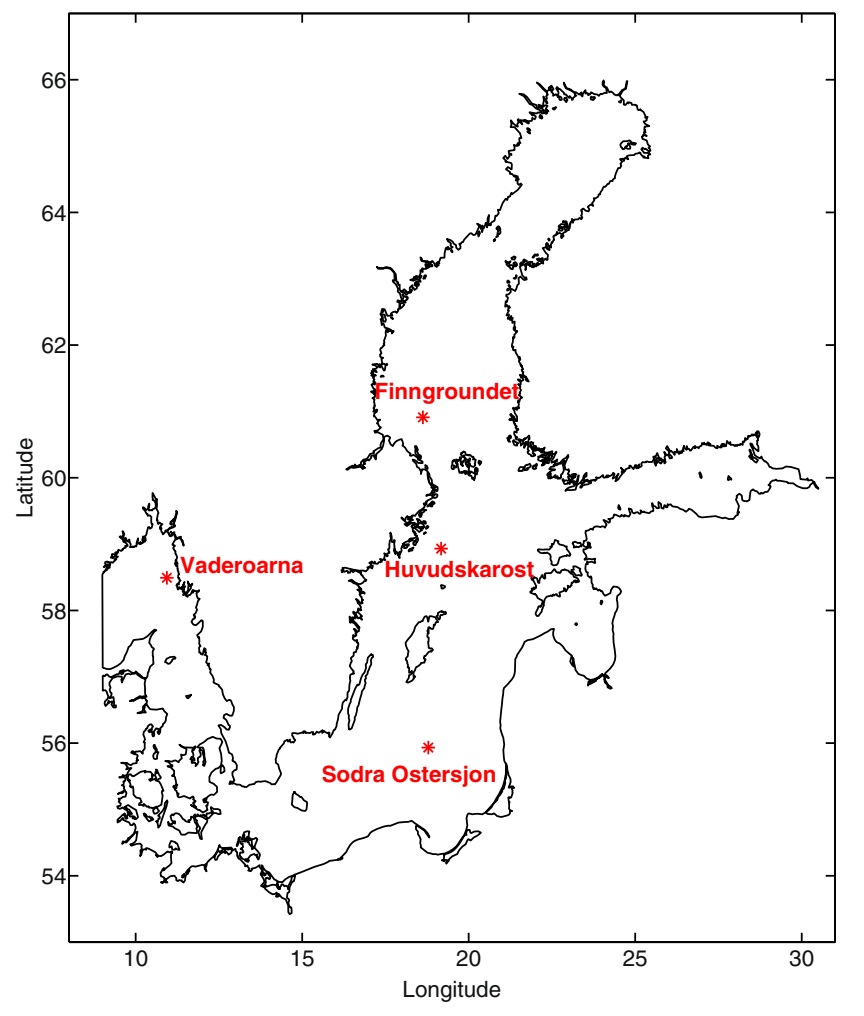

Fig. 7 Locations of the buoys used for the comparison of the sea surface temperature

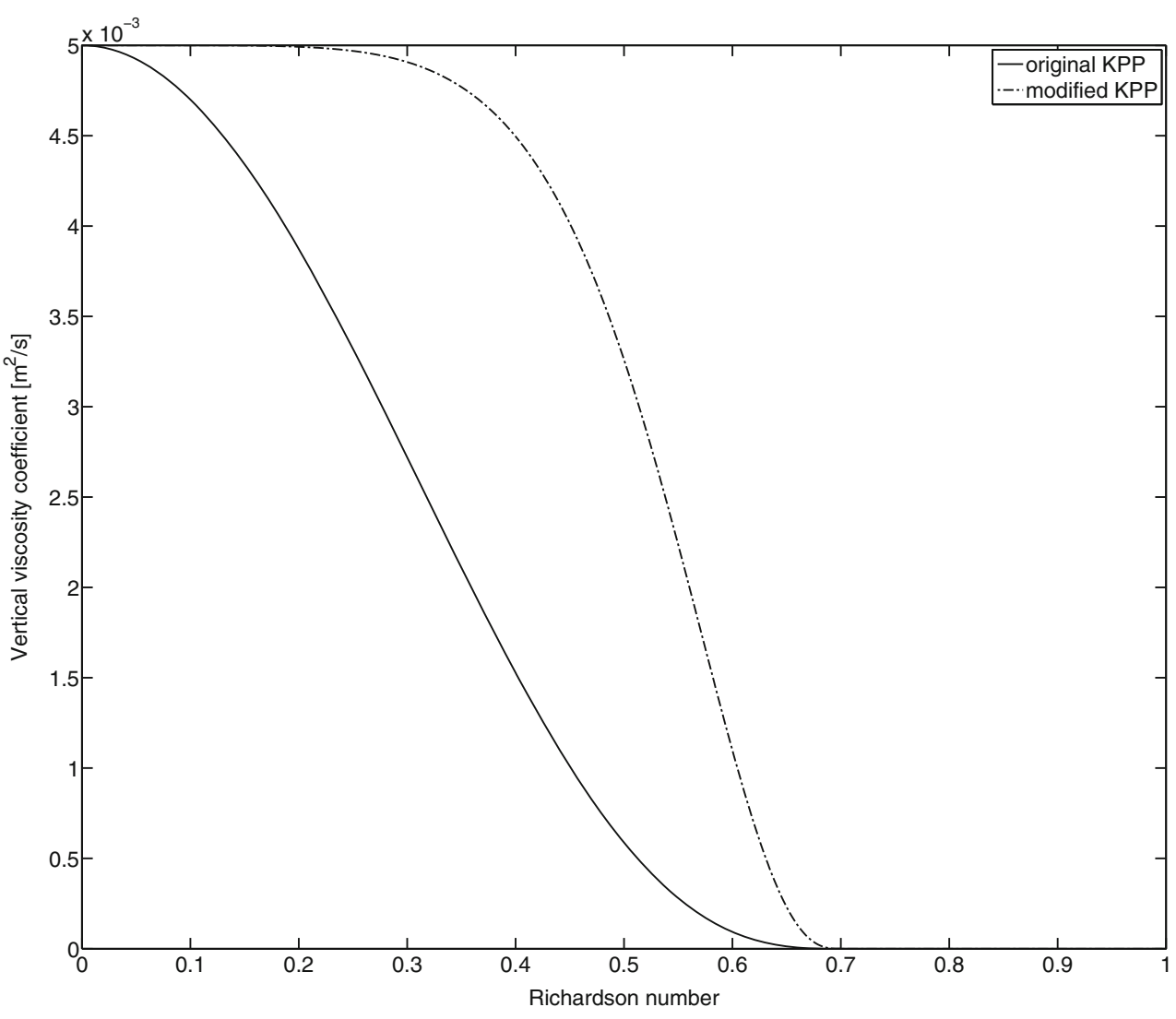

estimation, and it varied here in the day/night regime. During daytime, the NOAA $0.25^{\circ}$ Reynolds daily composite after Optimal Interpolation had been used (SST). In other cases, the SST4 product described below had been used as reference (NSST). The second type of the SST is MODISspecific. Due to the fact that MODIS has two bands in the MIWR part of the electromagnetic spectrum, the SST4 product had been based on the brightness temperature measured in 22nd and 23rd MODIS bands (at 3.959 and $4.050 \mu \mathrm{m})$. At this wavelengths, the atmosphere is more transparent and less variable than at the longer ones, which leads to higher accuracy. However, due to sunlight contamination, it is not recommended for daytime use (Kilpatrick et al. 2015).

Figure 8 shows a good agreement between observational data and model results. The model provides average temperature in the upper 5-m thick layer, whereas the satellite data represent sea temperature at the surface (usually the skin temperature). Therefore, the modeled sea surface temperature is lower than the measured one in summer and higher in winter. Validation of the modeled SST against satellite data is complemented by a comparison of 1-year long-time series of temperature and salinity profiles from the HuvudskarOst station (location shown on Fig. 7). Despite numerous gaps in in situ measurements, they can be still used for validation of the model results 

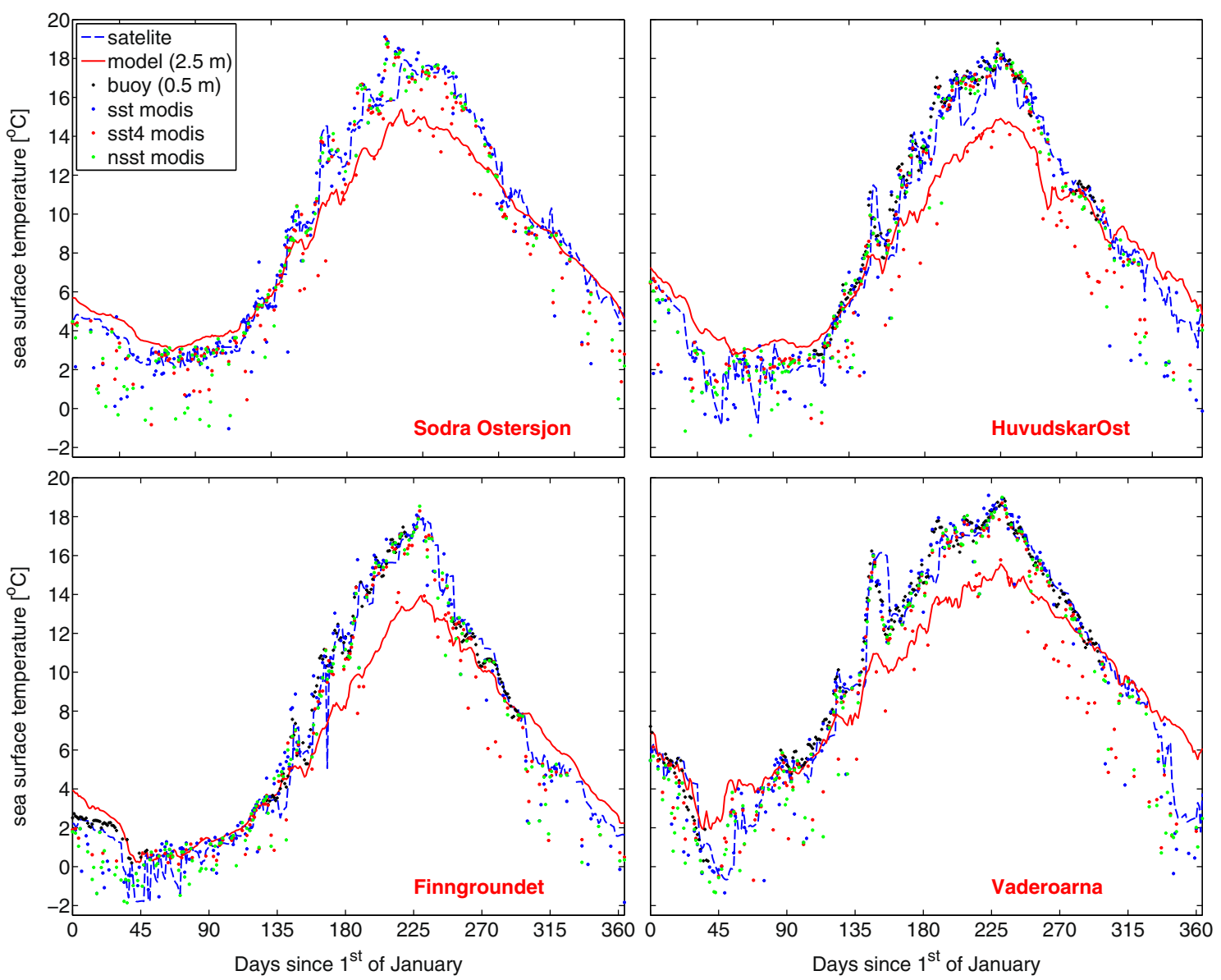

Fig. 8 A comparison of the modeled and observed sea surface temperature at four different locations (based on daily data, results are for year 2012)

in terms of the vertical distribution of temperature and salinity and their seasonal variability. Figure 9 shows that model satisfactorily reproduces temporal evolution of vertical profiles of temperature and salinity. Stratification, represented by depths of individual isotherms and isohalines is similar in observations and model results, and seasonal variability of both properties in the upper layer (there is not enough observational data in the deeper layers) is well reproduced by the model.

\section{Ice model description and implementation for the Baltic Sea}

The second active component in the presented Baltic Sea model is the Los Alamos sea ice model-Community Ice CodE (CICE, Bailey et al. 2012). CICE is a descendant of the basin-scale dynamic-thermodynamic and thickness distribution ice model (Hibler 1979, 1980). The physics in the uncoupled ice model is the same as for the ice model used in the fully coupled system. The CICE model is based on the energy conserving thermodynamics of
Bitz and Lipscomb (1999). It contains multiple layers in each thickness category and takes into account the effects of brine pockets within the sea ice. The ice dynamics utilizes the elastic-viscous-plastic (EVP) rheology of Hunke and Dukowicz (1997, 2002). Sea ice ridging follows Rothrock (1975) and Thorndike et al. (1975). CICE has several interacting components: a thermodynamic model that computes local growth rates of snow and ice due to vertical conductive, radiative, and turbulent fluxes, along with snowfall; a model of ice dynamics, which predicts the velocity field of the ice pack based on a model of the material strength of the ice; a transport model that describes advection of the a real concentration, ice volumes and other state variables; and a ridging parameterization that transfers ice among thickness categories based on energetic balances and rates of strain. The CICE also has multiple thickness categories and ice thickness distribution evolves in time (CICE Scientific Reference). CICE has been successfully used in many regional and global adaptations (for example, Rinke et al. 2003; McLaren et al. 2006; Dzierzbicka-Głowacka and Jakacki 2013; Herman et al. 2011). 
Fig. 9 Temporal evolution of measured and modeled salinity (two upper panels) and temperature (two lower panels) profiles
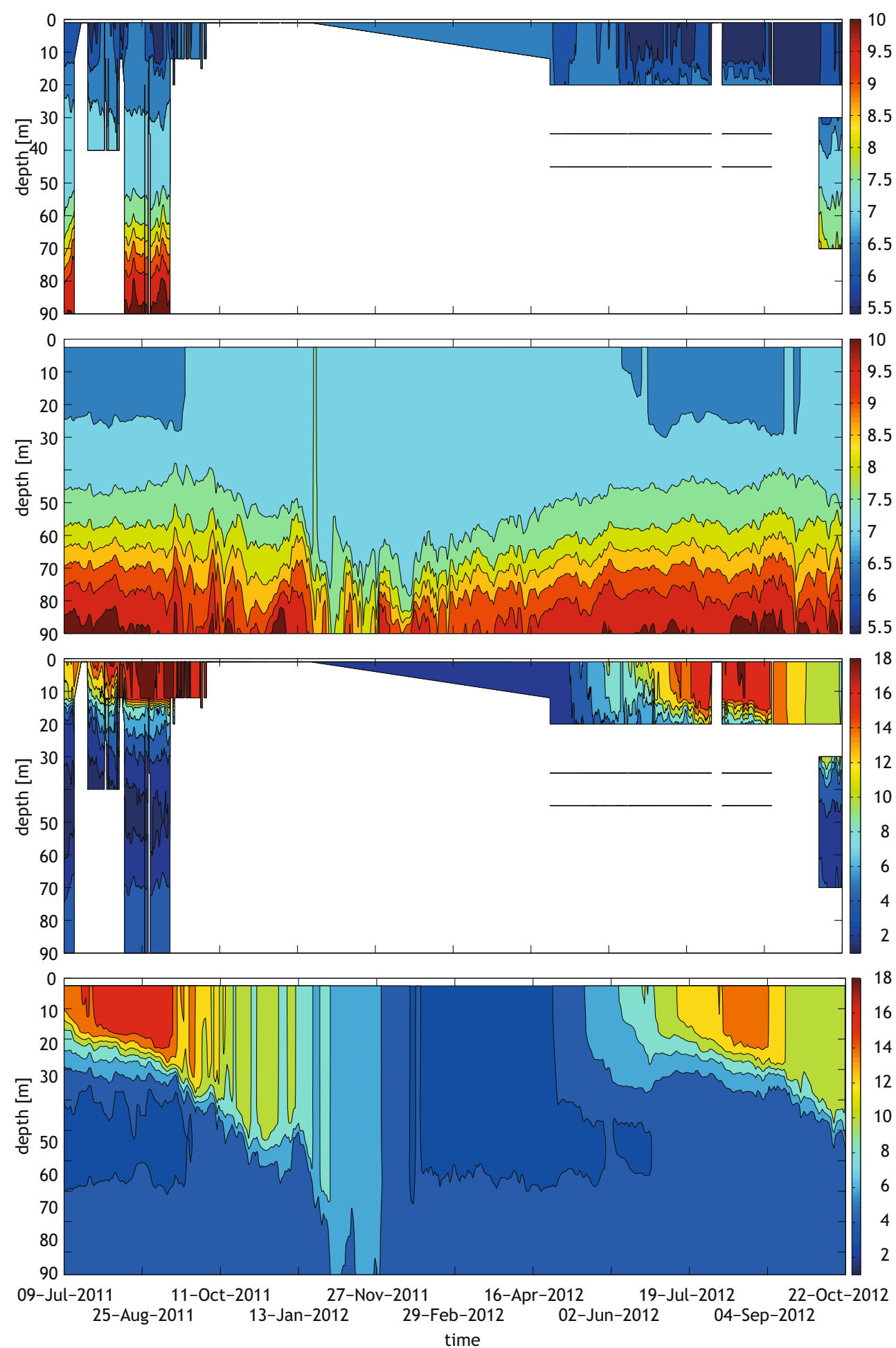

The model does not require a spin up because sea ice disappears in the Baltic Sea every summer. Horizontal resolution of $1 / 48^{\circ}$ (about $2.3 \mathrm{~km}$ ) is the same as in the ocean model. It has been configured for five vertical categories. The time step in the ice model of $600 \mathrm{~s}$ is the same as the coupler time step.

\subsection{Fluxes at the ice-ocean and atmosphere-ice interfaces}

Generally, heat and momentum fluxes, which influence the sea ice are similar to the ocean-atmosphere fluxes at the open ocean surface. The main difference is due to the ice 

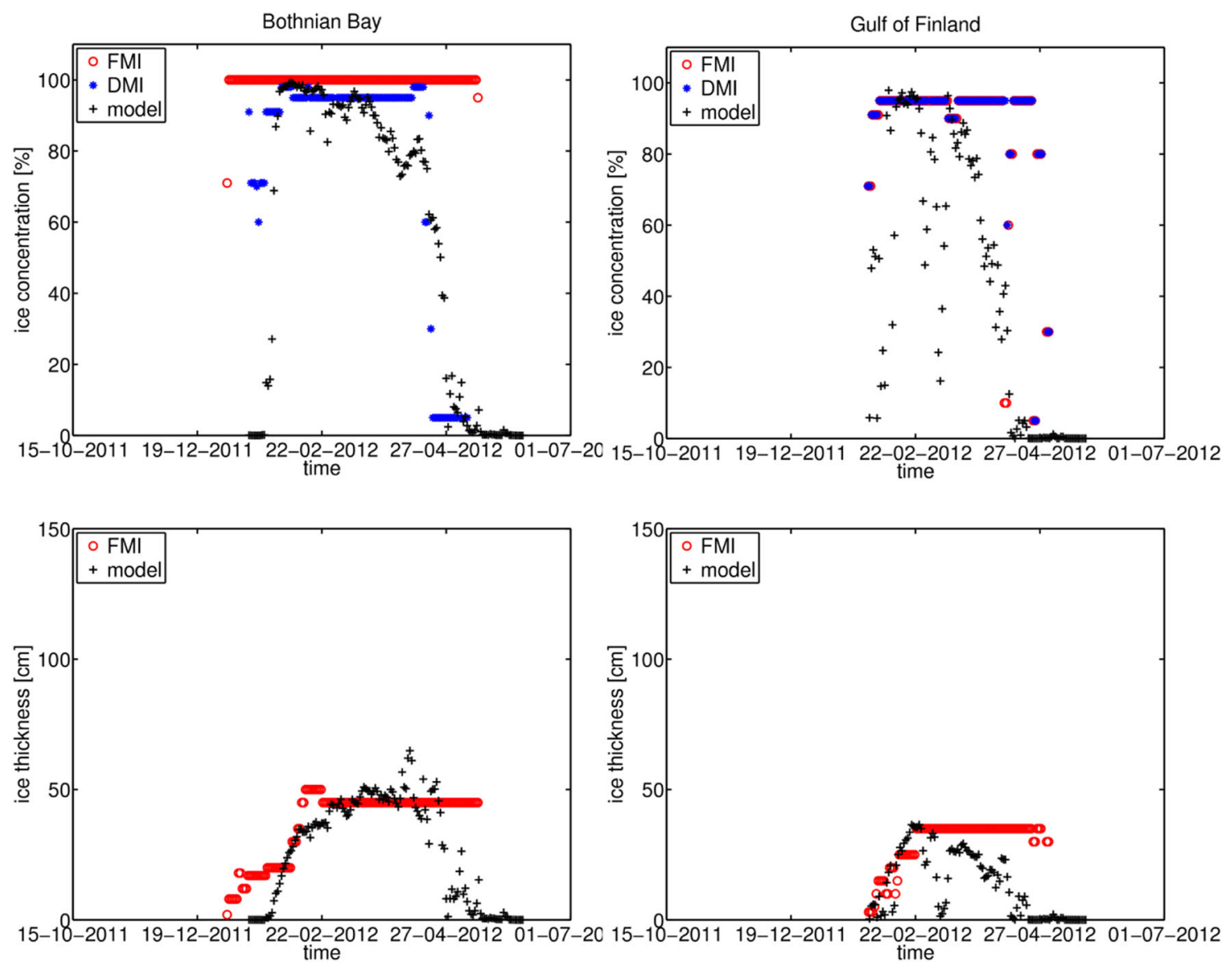

Fig. 10 Comparison of the measured (FMI, DMI) and modeled ice concentration and thickness for the Bothnia Bay (left) and the Gulf of Finland (right)

albedo and ice area. The net energy flux from atmosphere to ice is calculated based on the heat budget:

$Q_{\mathrm{net}}=i_{o}\left[(1-\alpha) Q_{\mathrm{sw}}+Q_{\mathrm{lw}}+Q_{\mathrm{lat}}+Q_{\mathrm{sen}}\right]$

where $i_{o}$ is ice fraction and $\alpha$ is ice albedo.

Momentum flux required by ice model is based on the nonlinear integral boundary layer theories (Hibler and Bryan 1987). Ocean and air momentum fluxes are calculated with the following equations:

$\tau_{a}=\rho_{a} C_{a}\left|U_{g}\right|\left(U_{g} \cdot \cos \phi+\mathbf{k} \times U_{g} \cdot \sin \phi\right)$

$\tau_{w}=\rho_{w} C_{w}\left|U_{w}-u\right|\left(\left(U_{w}-u\right) \cdot \cos \theta+k \times\left(U_{w}-u\right) \cdot \sin \theta\right)$

where $u$ represents the sea ice velocity, $U_{g}$ is the geostrophic wind velocity (assumed to be higher than the ice motion velocity), $U_{w}$ is the ocean surface velocity, $c_{a}$ and $c_{w}$ are air and water drag coefficients, $\rho_{a}$ and $\rho_{w}$ are air and ocean density, and phi and $\theta$ are air and water turning angles.

\subsection{Ice model validation and results}

Sea ice is the key element of the whole Baltic Sea system. Numerous satellite products exist that can be used to validate the Baltic Sea model but only few are suitable for sea ice validation. Under the MyOcean framework (currently known as the Copernicus Marine Environment Monitoring Service), two sea ice datasets are available - the first from the Danish Meteorological Institute (DMI) and the second provided by Finnish Meteorological Institute (FMI). The FMI data include sea ice concentration and thickness over the entire Baltic Sea and are available as daily data with the horizontal resolution of $1 \mathrm{~km}$. DMI provides only sea ice concentration with a $2-\mathrm{km}$ resolution. Both observational datasets are based on SAR images. The operational sea ice service at FMI provides ice parameters, produced on a daily basis during the Baltic Sea ice season. The ice thickness chart (ITC) is a product based on the most recent available ice chart (IC) and a SAR image. The DMI data are also based on the operational product.

Figure 10 shows a comparison between the modeled and the measured ice thickness and concentration for 
Fig. 11 Modeled (left) and measured (SAR) mean level ice thickness for the most of the Baltic Sea area (06-07.01.2003, color scales represent ice thickness in $\mathrm{cm}$ )

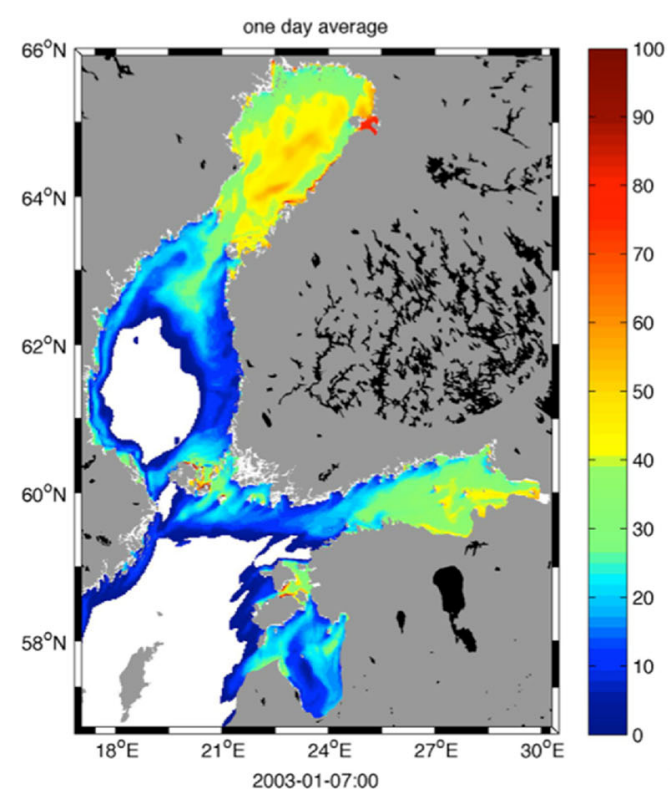

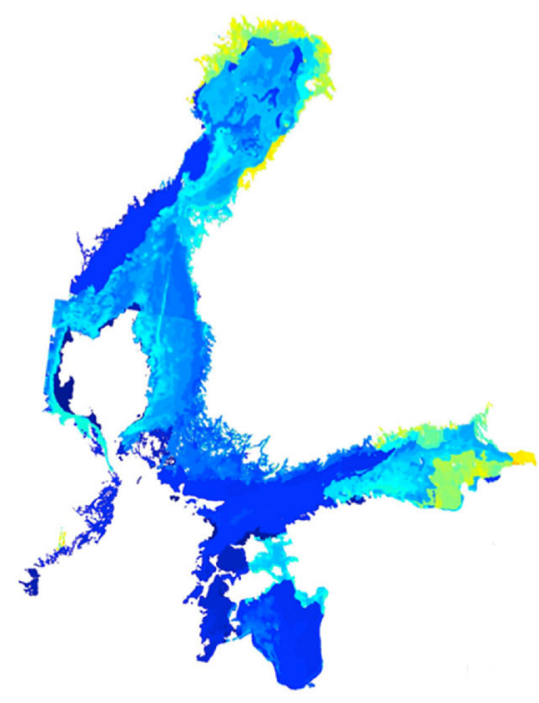

two different points, mostly covered by ice. The first one (Fig. 10, left panel) is located in the Bothnian Bay $\left(24.2944^{\circ} \mathrm{E}, 65.2023^{\circ} \mathrm{N}\right)$, while the second one lays in the Gulf of Finland $\left(28.6988^{\circ} \mathrm{E}, 60.1510^{\circ} \mathrm{N}\right)$. It is clearly visible that variability of ice concentration and thickness provided as operational products is much lower than modeled values. The cause of it is unknown, yet it is suspected that SAR fails to sense minor changes in ice thickness and concentration. Even if the SAR data do not fully resolve the short-term variability, the ranges of measured and modeled sea ice concentration and thickness are similar as well as their changes on longer times scales.
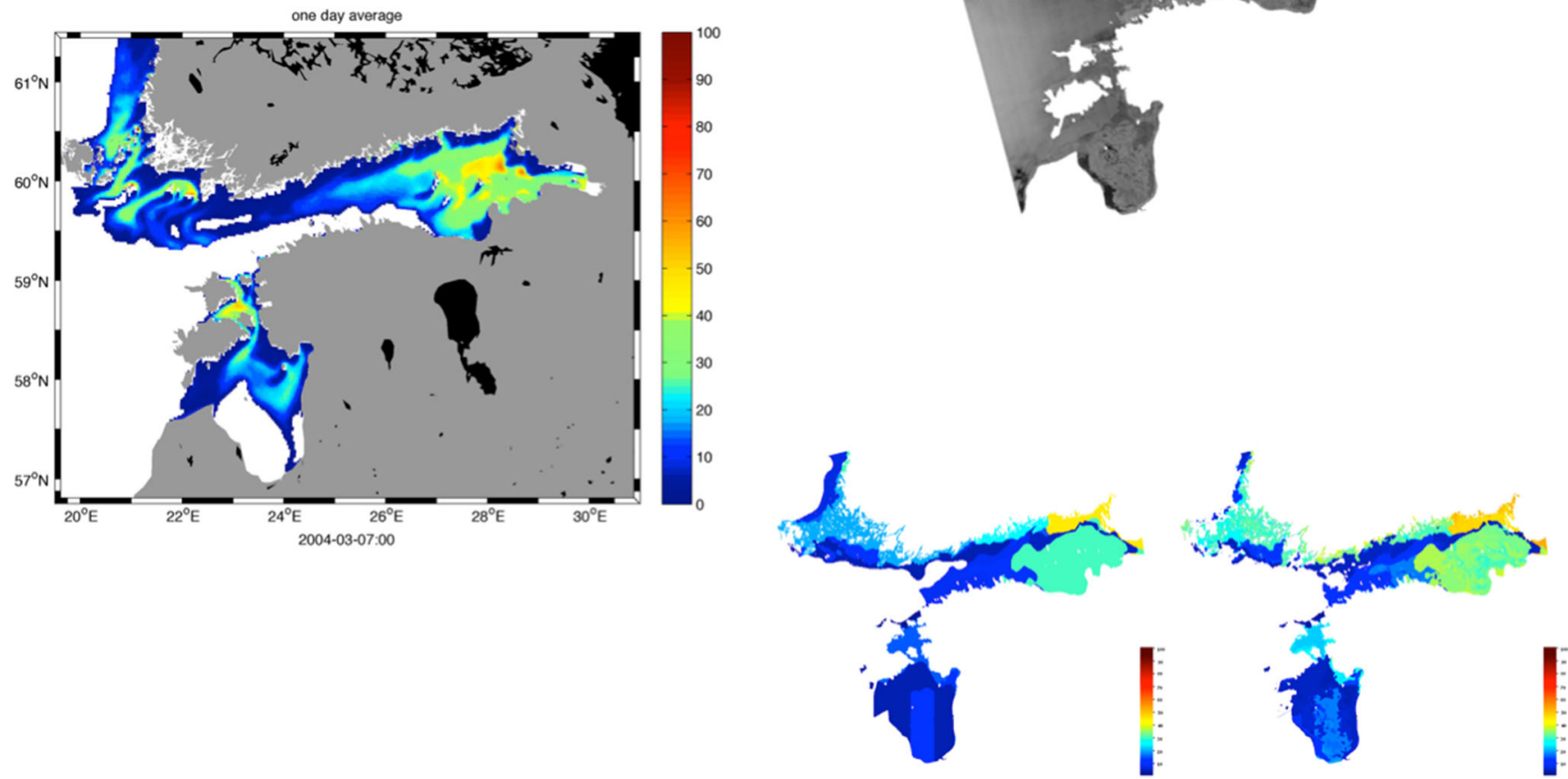

Fig. 12 Mean level ice thickness generation process based on the data from SAR (three right images) and modeled ice thickness for the same day (07.03.2004, color scale represents ice thickness in $\mathrm{cm}$ ) 


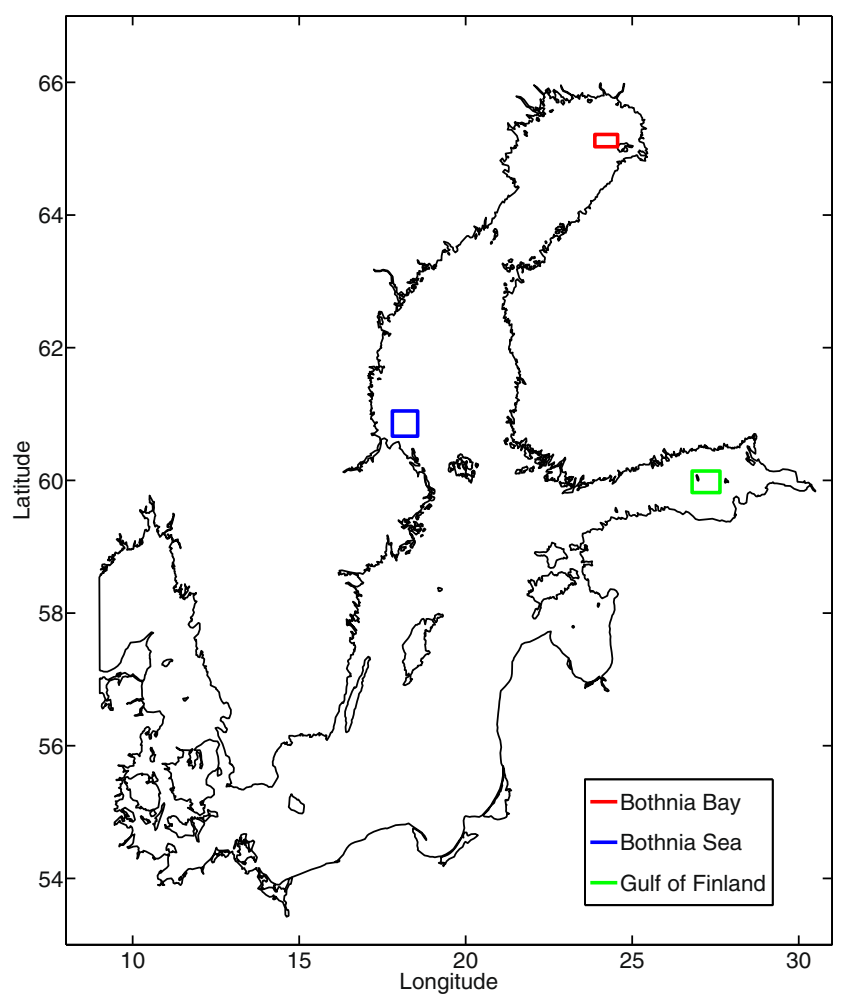

Fig. 13 Locations of rectangles taken into account for validation of the ice cover

Since daily ice charts (IC), produced by the Finnish Ice Service during each ice season, are available only as images, it is difficult to compare them with model results. To obtain more relaible validation, the sea ice thickness reproduced by the B-CESM model was compared to a combined product of SAR data and thermodynamic ice model HIGHTSI (highresolution thermodynamic snow/ice model). HIGHTSI is a coupled snow and sea ice one-dimensional physical model targeted to determine the snow/ice surface temperature, insnow/ice temperature and snow/ice thickness at a selected site (Karvonen et al. 2003, 2007, 2008). Figures 11 and 12 present a comparison of sea ice thickness simulated with the presented B-CESM model with available ice charts based on SAR data combined with the thermodynamical ice model. The modeled and derived from SAR/HIGHTSI mean level ice thickness do not match ideally, but spatial patterns are similar in both cases. In particular, a distribution and shapes of the open water areas are well reproduced by the Baltic Sea model. Ice thickness in the Gulf of Finland is in the range between 10 and $30 \mathrm{~cm}$ in both cases. In the Gulf of Bothnia sea, ice is approximately $15 \mathrm{~cm}$ thicker than the value obtained from the SAR/HIGHTSI data. Sea ice thickness is similar in both cases also in the Gulf of Riga.

To obtain an optimum balance between validation of sea ice parameters in the single location (precise but not very reliable) and validation for the sub-basins of the Baltic Sea (reliable but not sufficiently precise), in the next step, we compare sea ice parameters averaged in the selected boxes, representative for different parts of the Baltic Sea. Locations of the rectangles are shown on Fig. 13.

The selection of boxes is based on the Climatological Ice Atlas for the Baltic Sea CIABS (1982). Ice frequency, average ice thickness, and probability of ice occurrence within three ranges of thickness $(0-20 \mathrm{~cm}, 20-50 \mathrm{~cm}$, and thicker than $50 \mathrm{~cm}$ ) are shown on Fig. 14 for three selected boxes in the Bothnian Bay, the Bothnian Sea, and the Gulf of Finland. Each panel of Fig. 14 shows a comparison of three model simulations (A, B, and C) with climatological data obtained for each box from CIABS and data from Swedish Ice Service (SIS) provided by SMHI. It is important to add that simulations and data cover different time periods. Data from CIABS are provided for years 1963-1979, SIS are for time period 2007-2013. The model simulation A was for a 9-km horizontal resolution and was forced by ERA40 reanalysis. Simulations B and C are identical except external atmospheric forcing. B was forced by ERA40 and C was forced by ERA Interim (both are reanalysis provided by ECMWF).

The best agreement between the modeled and measured sea ice variables was obtained in the box located in the Bothnian Bay (Fig. 14, left panels). Ice frequency and averaged ice thickness from the simulation A almost ideally agrees with climatological data, while in the second and third simulations (B and $\mathrm{C}$ ) reproduced ice thickness slightly higher than observed. Furthermore, there is a very good agreement between the measured and the modeled probabilities of sea ice occurrence in different thickness classes. The shapes of probabilities reflect the natural variability of sea ice thickness. In the beginning of winter, thin ice appears. Then, ice thickness increases, which is visible in higher probabilities of ice thickness in the range of $20-50 \mathrm{~cm}$. After some time, lag ice thickness reaches $50 \mathrm{~cm}$ and more. These time shifts are visible in the probability distributions. Towards the end of winter, melting processes result in decreasing thickness of sea ice cover. It is reflected in a visible symmetry (quasi-symmetry) of probability that ice thickness is in the range of $0-20 \mathrm{~cm}$.

In the beginning of November, sea ice appears in the northern part of the Bothnian Bay. Then, the freezing process spreads southwards. The range of values and temporal evolution of sea ice frequency and average ice thickness are similar in all boxes. The average ice thickness in the Bothnian Sea simulated by the model is lower than obtained from climatology. We think the differences in the ice probability shown for Bothnia Sea and Gulf of Finland suggest there could be problem with ice dynamics. Ice cover in Bothnia Bay is much stable, and influence of sea currents is smallest comparing to Bothnia Sea and Gulf of Finland. 

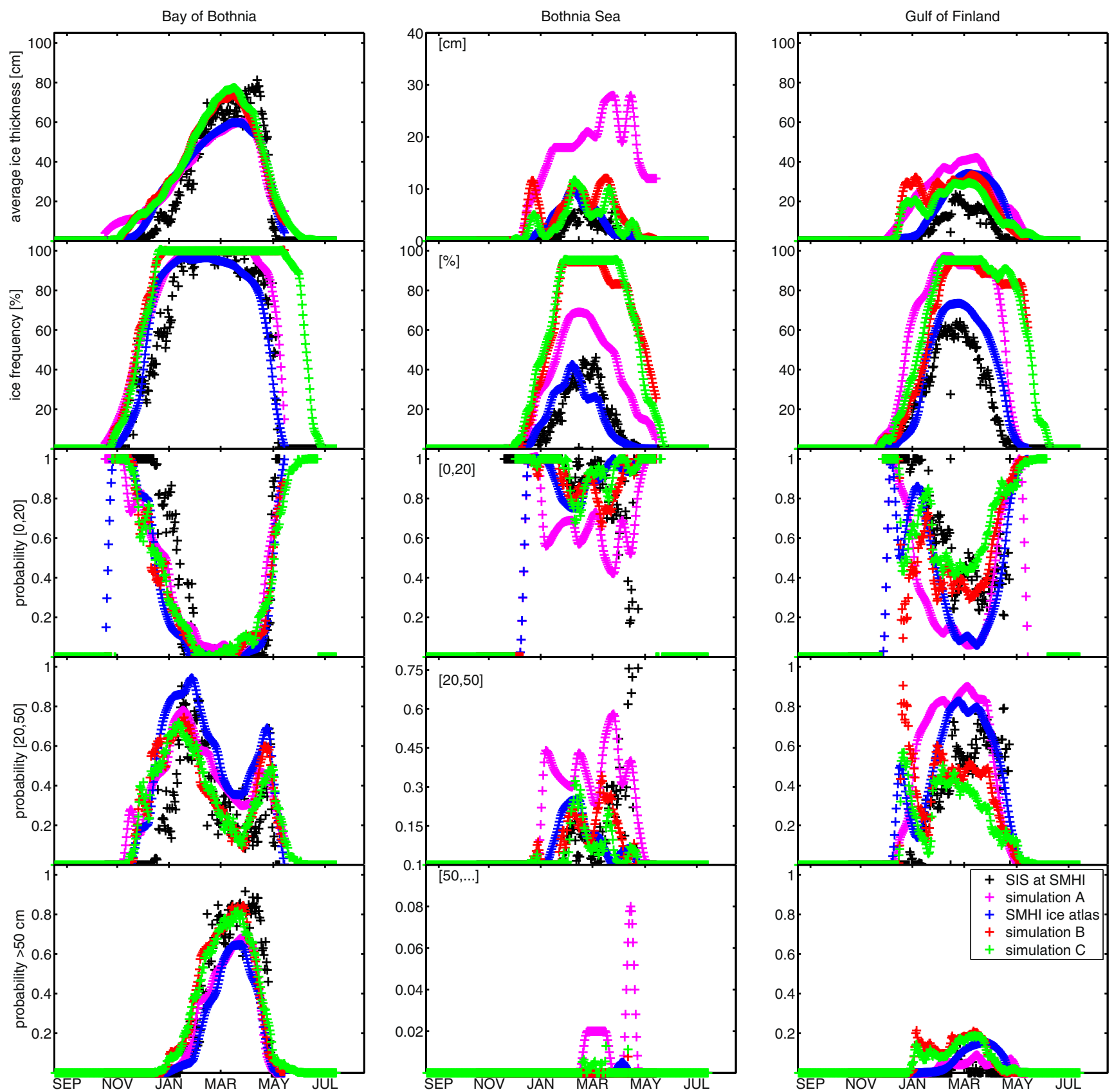

Fig. 14 Ice frequency, average ice thickness and probability that ice thickness is less then $20 \mathrm{~cm}$, between 20 and $50 \mathrm{~cm}$ and above $50 \mathrm{~cm}$ for three boxes indicated on Fig. 13 (the Bothnia Bay, the Bothnia Sea, and the Gulf of Finland shown column-wise from left to right)

Long-term variability of ice cover in the Baltic Sea is shown on Fig. 15a as maximum annual sea ice extent since the 18th century (Seinä and Kalliosaari 1991, Seinä and Palosuo 1996; Seinä et al. 1996, 2001, 2006). The black line depicts yearly values, the red line shows 15 -year moving average, and the modeled maximum sea ice extent has been overlaid for the last two decades (green line).

The maximum Baltic Sea annual ice extent has been slowly decreasing for the last two centuries. After a strong drop observed in the beginning of 1990 s due to unknown reasons, the sea ice maximum extent has been increasing again. Figure $15 \mathrm{~b}$ shows the detailed comparison between modeled and climatological sea ice extent for this period. The linear regression between modeled and measured data provides the correlation coefficient higher than 0.9 , as shown by the insert on Fig. 15b.

Furthermore, an increase in the ice cover is also visible during years 1990-2008. The main factor that could cause a visible positive trend of ice extent is temperature. However, global warming has been observed in recent 

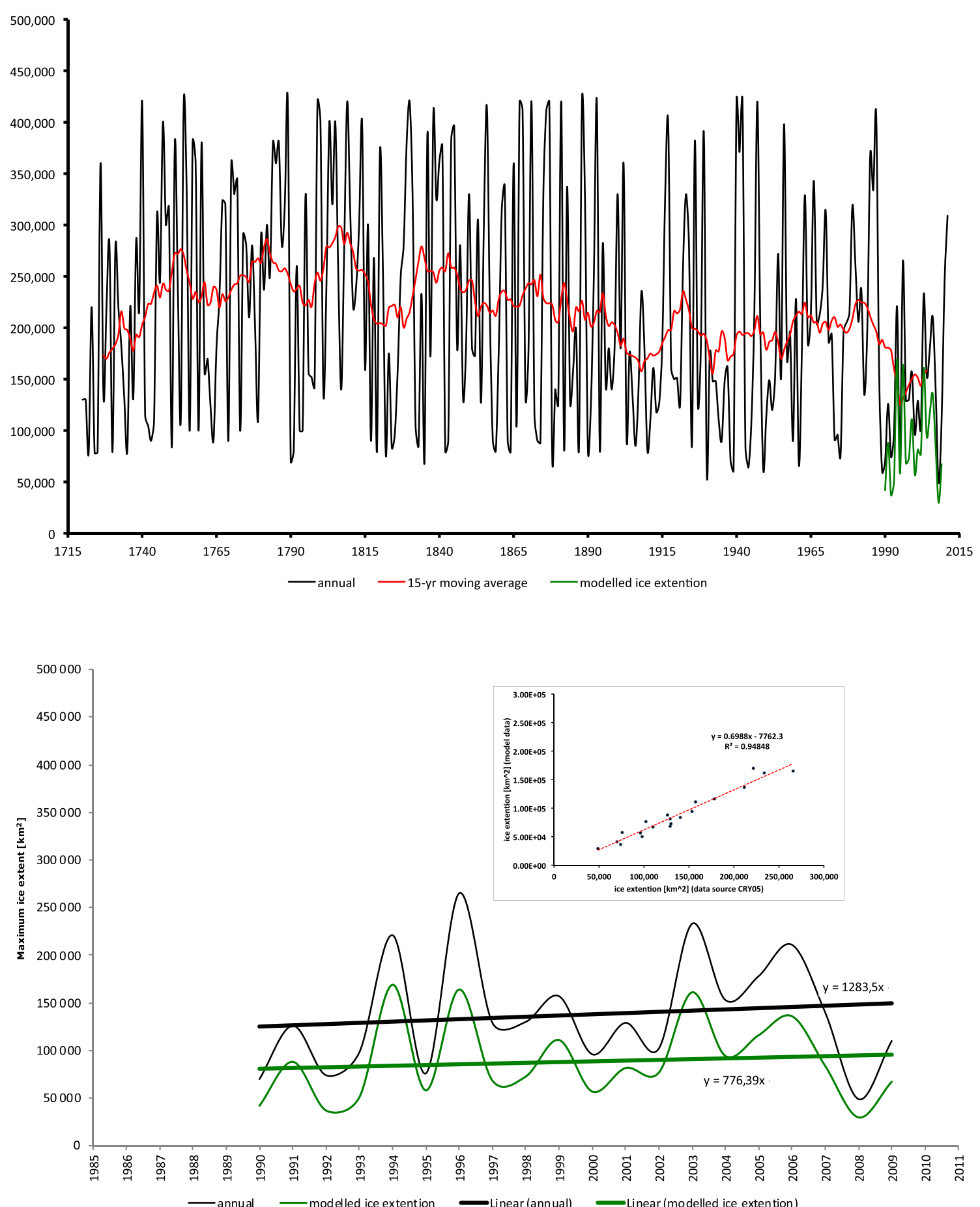

Fig. 15 a Maximum annual extent of ice cover in the Baltic Sea since 1720 (Seinä and Palosuo 1996; Seinä et al. 2001, 2006). b Maximum annual sea ice extent in the Baltic Sea in the last two decades

from observations and B-CESM (and correlation between modeled and observational data as an insert, linear trends have been included)

decades (Stroeve et al. 2007), and it could suggest that the Baltic Sea ice extent should have a negative tendency. Cohen et al. (2014) shown that for the years 1990-2013 DJF (December,January and February) surface temperature trends (per decade) are negative or neutral over the Baltic Sea area (Fig. 16), which could explain the trend.
Another, much less important factor that could have influence on the ice extent is fresh water from the catchment area. The Baltic Sea runoff is an important part of the fresh water budget. In general, freshwater flux minus evaporation is positive and has a strong influence on the Baltic Sea circulation. Meier (2003) showed that the mean 


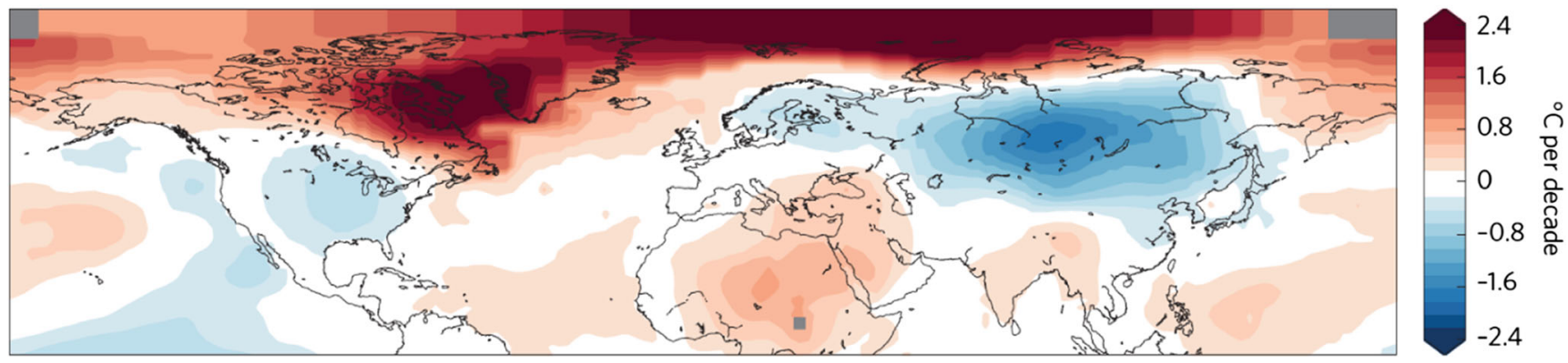

Fig. 16 Winter temperature trends for the most recent period from 1990 (Cohen et al. 2014)

winter runoff (January, February and March-JFM) has been increasing since around 1970. The influence of runoff on the ice extent is much lower then heat budget, but excessive runoff decreases sea surface salinity. It is well-known that freezing temperature depends on salinity and is going down when salinity increases (the lowest freezing temperature of the oceans is about $-1.8^{\circ} \mathrm{C}$. Additional fresh water amount can decrease salinity, which is equivalent to increasing freezing temperature, and as a consequence, it could accelerate growth of the ice extent. But, salinity of the freezing part of the Baltic Sea is very small (usually less then 5); thus, influence of this process is very small.

\section{Summary}

High-resolution coupled ice-ocean model has been successfully developed and implemented for the small regional domain of the Baltic Sea area. The main modification has been done in the ocean component, which represents the lower boundary layer of the ice component. The model is based on a new open-source product-CESM. Both components (ice and ocean) were validated and the validation confirms quite good agreement with the in situ and satellite measurements. Furthermore, evidence confirming increased ice extent was shown for the last two decades. It is an impact of the negative trend of winter air temperature since 1990 over the Baltic Sea are and also a consequence of increasing winter fresh water discharge in this period, which results in the rise of freezing temperature, which in turn increases the ice extent. The main problem that appeared in the model is lower oscillations of the sea level, which is the result of linear approximation of free-surface parameterization. In the future, it is planned to implement another free-surface scheme (probably nonlinear implicit), which will fix the problem.

Funding information The study was financially supported by the Polish State Committee of Scientific Research (grant: No N N305 111636). The partial support for this study was also provided by the project Satellite Monitoring of the Baltic Sea EnvironmentSatBaltyk founded by European Union through European Regional
Development Fund contract no. POIG 01.01.02-22-011/09. This work was also partially carried out within the framework of projects DAIMON (European Regional Development Fund (Interreg), R013 DAIMON) and MODUM (North Atlantic Treaty Organization (NATO EAP.SFPP 984589). The project was co-financed from the funds of the Ministry of Science and Higher Education (The National Centre for Research and Development, co-financed collaboration, project number 3055/NATO/2014/0). This work was also supported by the National Centre for Research and Development within the BIOSTRATEG III program No. BIOSTRATEG3/343927/3/NCBR/2017. The research was supported by the Ministry of Science and Higher Education in Poland in the frame of co-financed international project agreement no 3808/FAO/2017. Additionally we thank ARGO-Poland project for providing data for model validation. Calculations were carried out at the Academic Computer Centre in Gdańsk).

Open Access This article is distributed under the terms of the Creative Commons Attribution 4.0 International License (http:// creativecommons.org/licenses/by/4.0/), which permits unrestricted use, distribution, and reproduction in any medium, provided you give appropriate credit to the original author(s) and the source, provide a link to the Creative Commons license, and indicate if changes were made.

\section{References}

Almroth-Rosell E, Eilola K, Hordoir R, Meier HEM, Hall POJ (2011) Transport of fresh and resuspended particulate organic material in the Baltic Sea-a model study. J Mar Syst 87:1-12. https://doi.org/10.1016/j.jmarsys.2011.02.005

Amante C, Eakins BW (2009) ETOPO1 1 arc-minute global relief model: procedures, data sources and analysis. NOAA Technical Memorandum NESDIS NGDC-24. National Geophysical Data Center, NOAA. https://doi.org/10.7289/V5C8276M

Andrejev O, Sokolov A, Soomere T, Värv R, Viikmäe B (2010) The use of high- resolution bathymetry for circulation modelling in the Gulf of Finland. Est J Eng 16:187-210

Arheimer B, Dahne J, Donnelly C (2012) Climate change impact on riverine nutrient load and land-based remedial measures of the Baltic Sea Action Plan. AMBIO 122(1-2):157-170

Bailey D, Holland M, Hunke E, Lipscomb B, Briegleb B, Bitz C, Schramm J (2012) Community Ice CodE (CICE) User's Guide Released with CESM1. 0, 23. (http://www.cesm.ucar.edu/models/ cesm1.1/cice/doc/index.html)

Berrisford P, Dee D, Poli P, Brugge R, Fielding K, Fuentes M, Kallberg P, Kobayashi S, Uppala S, Simmons A (2011) The ERAInterim Archive, Version 2.0. ERA Report Series. 1 (Technical Report). ECMWF, 23 pp 
Bitz CM, Lipscomb WH (1999) An energy-conserving thermodynamic model of sea ice. J Geophys Res 104(C7):15669. https://doi.org/10.1029/1999JC900100

Blackmon MB, Boville B, Bryan F, Gent P, Kiehl J, Moritz R, Hurrel J (2001) The community climate system model. Bull Am Meteorol Soc 82(11):2357-2376

Bryan K (1969) A numerical method for the study of the circulation of the world ocean. J Comput Phys 4:347-376. https://doi.org/10.1016/0021-9991(69)90004-7

Burchard H, Petersen O (1999) Models of turbulence in the marine environment-a comparative study of two-equation turbulence models. J Mar Syst 21:29-53

Carlsson M (1997) Sea level and salinity variations in the Baltic Sea-an oceanographic study using historical data. Department of Oceanography, Gøteborg University, Gøteborg

Cassano J, Maslowski W, Gutowski W, Lettenmaier D, He J (2010) Development of a Regional Arctic Climate System Model (RACM). State of the arctic conference: at the forefront of global change. Miami

Climatological ice atlas for the Baltic Sea Kattegat, Skagerrak (1982) Swedish Meteorological and Hydrological Institute, Norrköping, Sweden and Institute of Marine Research, Helsinki, Finland

Cohen J, Screen JA, Furtado JC, Barlow M, Whittleston D, Coumou D, Francis J, Dethlof K, Entekhabi D, Overland J, Jones J (2014) Recent Arctic amplification and extreme mid-latitude weather. Nat Geosci 7(9):627-637. https://doi.org/10.1038/ngeo2234

Cox MD, Laboratory, Geophysical Fluid Dynamics (1984) A primitive equation, 3-dimensional model of the ocean. GFDL Ocean Group technical report, Geophysical Fluid Dynamica Laboratory/NOAA, Princeton University

Cressman GP (1959) An operational objective analysis system. Mon Weather Rev 87(1959):367-374

Daewel U, Schrum C (2013) Simulating long-term dynamics of the coupled North and Baltic Sea ecosystem with ECOSMO II: model description and validation. J Mar Syst. https://doi.org/10.1016/j.marsys.2013.03.008

Dee DP, Uppala SM, Simmons AJ, Berrisford P, Poli P, Kobayashi S, Andrae U, Balmaseda MA, Balsamo G, Bauer P, Bechtold P, Beljaars ACM, van de Berg L, Bidlot J, Bormann N, Delsol C, Dragani R, Fuentes M, Geer AJ, Haimberger L, Healy SB, Hersbach H, Hólm EV, Isaksen L, Kållberg P, Köhler M, Matricardi M, McNally AP, Monge-Sanz BM, Morcrette J-J, Park BK, Peubey C, de Rosnay P, Tavolato C, Thépaut J-N, Vitart F (2011) The ERA-Interim reanalysis: configuration and performance of the data assimilation system. Q J R Meteorol Soc 137:553-597. https://doi.org/10.1002/qj.828

Dieterich C, Schimanke S, Wang S, Väli G, Liu Y, Hordoir R, Axell L, Höglund A, Meier HEM (2013) Evaluation of the SMHI coupled atmosphere-ice-ocean model RCA4-NEMO. SMHI Report Oceanography 47:80

Döscher R, Willén U, Jones C, Rutgersson A, Meier HEM, Hansson U, Graham LP (2002) The development of the regional coupled ocean-atmosphere model RCAO. Boreal Environ Res 7:183-192

Dukowicz JK, Smith R (1994) Implicit free-surface method for the Bryan-Cox-Semtner ocean model. J Geophys Res 99:7991-8014. https://doi.org/10.1029/93JC03455

Durski SM, Glenn SM, Haidvogel DB (2004) Vertical mixing schemes in the coastal ocean: comparison of the level 2.5 Mellor-Yamada scheme with an enhanced version of the $\mathrm{K}$ profile parameterization. J Geophys Res 109(C1):C01015. https://doi.org/10.1029 /2002JC001702

Dzierzbicka-Głowacka L, Jakacki J (2013) Activation of the operational ecohydrodynamic model (3D CEMBS) - the hydrodynamic part. Oceanologia 55(3):519-541. https://doi.org/10.5697/ oc. $55-3.519$
Edman M, Omstedt A (2013) Modeling the dissolved CO2 system in the redox environment of the Baltic Sea. Limnol Oceanogr 58(1):74-92

Eilola K, Meier HEM, Almroth E (2009) On the dynamics of oxygen, phosphorus and cyanobacteria in the Baltic Sea; a model study. J Mar Syst 75:163-184

Eilola K, Gustafson BG, Kuznetsov I, Meier HEM, Neumann T, Savchuk OP (2011) Evaluation of biogeochemical cycles in an ensemble of three state-of-the- art numerical models of the Baltic Sea during 1970-2005. J Mar Syst 88:267-284. https://doi.org/10.1016/j.jmarsys.2011.05.004

Funkquist L, Kleine E (2007) An introduction to HIROMB, an operational baroclinic model for the Baltic Sea. SMHI Rep Oceanogr RO37, (37)

Graham LP (1999) Modeling runoff to the Baltic Sea. AMBIO 28:328-334

Graham LP (2004) Climate change effects on river flow to the Baltic Sea. AMBIO 33:235-241

Grode P (2004) Validation of sea levels and flow through the Danish straits in HIROMB and GETM in 2002. Royal Danish Administation of Navigation and Hydrography report (K.2)

Gräwe U, Friedland R, Burchard H (2013) The future of the western Baltic Sea: two possible scenarios. Ocean Dyn 63(8):901-921

Gustafsson N, Nyberg L, Omstedt A (1998) Coupling of a highresolution atmospheric model and an ocean model for the Baltic Sea. Mon Weather Rev 126:2822-2846

Gustafsson E, Deutsch B, Gustafsson BG, Humborg C, Mörth C-M (2014) Carbon cycling in the Baltic Sea-the fate of allochthonous organic carbon and its impact on air-sea CO2 exchange. J Mar Syst 129:289-302

Hack JJ, Boville BA, Briegleb BP, Kiehl JT, Rasch PJ, Williamson DL (1993) Description of the NCAR community climate model (CCM2). NCAR Tech. Note, 152

Hagedorn R, Lehmann A, Jacob D (2000) A coupled high resolution atmosphere-ocean model for the BALTEX region. Meteorol Z 9:7-20

Hense I, Meier HEM, Sonntag S (2013) Projected climate change impact on Baltic Sea cyanobacteria. Clim Chang 119:391-406. https://doi.org/10.1007/ s10584-013-0702-y

Herman A, Jedrasik J, Kowalewski M (2011) Numerical modelling of thermodynamics and dynamics of sea ice in the Baltic Sea. Ocean Sci 7:257-276. https://doi.org/10.5194/os-7-257-2011

Hibler WD (1979) A dynamic thermodynamic sea ice model. J Phys Oceanogr 9(4):815-846. https://doi.org/10.1175/15200485(1979)009<0815:ADTSIM > 2.0.CO;2

Hibler WD (1980) Modeling a variable thickness sea ice cover. Mon Weather Rev 108(12):1943-1973. https://doi.org/10.1175/15200493(1980)108<1943:MAVTSI > 2.0.CO;2

Hibler WD, Bryan K (1987) A diagnostic ice-ocean model. J Phys Oceanogr 17(7):987-1015. https://doi.org/10.1175/15200485(1987)017<0987:ADIM>2.0.CO;2

Höglund A, Meier HEM, Broman B, Kriezl E (2009) Validation and correction of regionalised ERA-40 wind fields over the Baltic Sea using the Rossby Centre Atmosphere Model RCA 3.0. SMHI Report Oceanografi. SMHI, SE-60176 Norrköping, Sweden, vol 97, 35pp

Hunke EC, Dukowicz JK (1997) An elastic_viscous—plastic model for sea ice dynamics. J Phys Oceanogr 27(9):1849-1867. https://doi.org/10.1175/1520-0485

Hunke EC, Dukowicz JK (2002) The elastic-viscous-plastic sea ice dynamics model in general orthogonal curvilinear coordinates on a sphere-incorporation of metric terms. Mon Weather Rev 130(7):1848-1865. https://doi.org/10.1175/1520-0493(2002) $130<1848:$ TEVPSI $>2.0$. CO 2

Hurrell JW, Holland MM, Gent PR, Ghan S, Kay JE, Kushner PJ, Lamarque JF, Large WG, Lawrence D, Lindsay K, Lipscomb WH, 
Long MC, Mahowald N, Marsh DR, Neale RB, Rasch P, Vavrus S, Vertenstein M, Bader D, Collins WD, Hack JJ, Kiehl J, Marshall S (2013) The community earth system model: a framework for collaborative research. Bull Am Meteorol Soc 94(9):1339-1360. https://doi.org/10.1175/BAMS-D-12-00121.1

Jakacki J, Przyborska A, Nowicki A, Wichorowski M, Przyborski M, Baloskorski M, Sochacki C, Tylman R (2017) eBalticGridan interactive platform for the visualisation of results from a high-resolution operational Baltic Sea model. Meteorol Hydrol Water Manag 5(2):13-20. https://doi.org/10.26491/mhwm/68898

Kalnay E, Kanamitsu M, Kirtler R, Collins W, Deaven D, Gandin L, Iredell M, Saha S, White G, Woollen J, Zhu Y, Chelliah M, Ebisuzaki W, Higgins W, Janowiak J, Mo KC, Ropelewski C, Wang J, Leetma A, Reynolds R, Jenne R, Joseph D (1996) The NCEP/NCAR 40-year reanalysis project. Bull Am Meteorol Soc $77: 437-471$

Kantha LH, Clayson CA (2000) Numerical models of oceans and oceanic processes. International Geophysics Series

Karvonen J, Simila M, Heiler I (2003) Ice thickness estimation using SAR data and ice thickness history. In: Proceedings of the IEEE international geoscience and remote sensing symposium (IGARSS'03), vol I. IEEE, pp 74-76

Karvonen J, Cheng B, Simila M (2007) Baltic sea ice thickness charts based on thermodynamic ice model and SAR data. In: Proceedings of the international geoscience and remote sensing symposium (IGARSS'07). IEEE, pp 4253-4256

Karvonen J, Cheng B, Simila M (2008) Ice thickness charts produced by C-band SAR Imagery and HIGHTSI thermodynamic ice model. In: Proceedings of the sixth workshop on Baltic Sea Ice Climate, pp 71-81

Killworth PD, Stainforth D, Webb DJ, Paterson SM (1991) The development of a free-surface Bryan-Cox-Semtner ocean model. J Phys Oceanogr 21:1333-1348

Kilpatrick KA, Podesta G, Walsh S, Williams E, Halliwell V, Szczodrak M, Brown OB, Minnett PJ, Evans R (2015) A decade of sea surface temperature from MODIS. Remote Sens Environ 165:27-41

Kuznetsov I, Neumann T (2013) Simulation of carbon dynamics in the Baltic Sea with a 3D model. J Mar Syst 111-112:167-174

Large WG, McWilliams JC, Doney SC (1994) Oceanic vertical mixing: a review and a model with a nonlocal boundary layer parameterization. Rev Geophys 32(4):363-403. https://doi.org/10.10 29/94RG01872

Lehmann A, Lorenz P, Jacob D (2004) Modelling the exceptional Baltic Sea inflow events in 2002-2003. Geophys Res Lett 31(21):L21308. https://doi.org/10.1029/2004GL020830

Li X, Chao Y, McWilliams JC, Fu L-L (2001) A comparison of two vertical mixing schemes in a Pacific Ocean general circulation model. J Climate 14:1377-1398

Lindström G, Johansson B, Persson M (1997) Development and test of the distributed HBV-96 hydrological model. J Hydrol 201(14):272-288

Lindström G, Pers CP, Rosberg R, Strömqvist J, Arheimer B (2010) Development and test of the HYPE (Hydrological Predictions for the Environment) model-a water quality model for different spatial scales. Hydrol Res 41(3-4):295-319

MacKenzie B, Meier HEM, Lindegren M, Neuenfeldt S, Eero M, Blenckner T, Tomczak M, Niiranen S (2012) Impact of climate change on fish population dynamics in the Baltic Sea: a dynamical downscaling investigation. AMBIO 41(6):626-636. https://doi.org/10.1007/s13280-012-0317-y

Majewski W (2015) Sustainable development of the lower Vistula. Meteorol Hydrol Water Manag 1(1):33-38

McLaren AJ, Banks HT, Durham CF, Gregory JM, Johns TC, Keen AB, Ridley JK, Roberts MJ, Lipscomb WH,
Connolley WM, Laxon SW (2006) Evaluation of the sea ice simulation in a new coupled atmosphere-ocean climate model (HadGEM1). J Geophys Res: Oceans 111(12):1-17. https://doi.org/10.1029/2005JC003033

Maslowski W, Cassano J, Gutowski W, Lettenmaier D (2009) Towards advanced understanding and predictive capability of climate change in the arctic using a high-resolution regional arctic climate system model (RACM). In: DOE climate change prediction program meeting, Bethesda

Maslowski W, Clement Kinney J, Higgins M, Roberts A (2012) The future of Arctic sea ice. Annu Rev Earth Planet Sci 40:625-54

Meier HEM (2003) Modeling decadal variability of the Baltic Sea: 2. Role of freshwater inflow and large-scale atmospheric circulation for salinity. J Geophys Res 108(C11):3368. https://doi.org/10.1029/2003JC001799

Meier HEM, Eilola K, Almroth E (2011) Climate-related changes in marine ecosystems simulated with a three-dimensional coupled biogeochemical-physical model of the Baltic Sea. Clim Res 48:31-55

Mohrholz V, Naumann M, Nausch G, Krüger S, Gräwe U (2015) Fresh oxygen for the Baltic Sea-an exceptional saline inflow after a decade of stagnation. J Mar Syst 148:152-166. https://doi.org/10.1016/j.jmarsys.2015.03.005

Mörth C-M, Humborg C, Eriksson H, Danielsson Å, Rodriguez Medina M, Löfgren S, Swaney DP, Rahm L (2007) Modeling riverine nutrient transport to the Baltic Sea: a large-scale approach. AMBIO 36(2):124-133

Mellor GL, Yamada T (1974) A hierarchy of turbulence closure models for planetary boundary layers. J Atmos Sci 31:1791-1806

Mellor GL, Yamada T (1982) Development of a turbulence closure model for geophysical fluid problems. Rev Geophys 20(1982):851-875

Mintz Y, Semtner AJ (1977) Numerical simulation of the Gulf Stream and mid-ocean eddies. J Phys Oceanogr 7(2):208-230. https://doi.org/10.1175/1520-0485(1977)007

Neumann T, Fennel W, Kremp C (2002) Experimental simulations with an ecosystem model of the Baltic Sea: a nutrient load reduction experiment. Glob Biogeochem Cycles 16(3):Article Number 1033

Niiranen S, Yletyinen J, Tomczak MM, Blenckner T, Hjerne O, MacKenzie B, Müller-Karulis B, Neumann T, Meier HEM (2013) Combined effects of global climate change and regional ecosystem drivers on an exploited marine food web. Glob Chang Biol 19:3327-3342. https://doi.org/10.1111/gcb.12309

Omstedt A, Hansson D (2006) The Baltic Sea ocean climate system memory and response to changes in the water and heat balance components. Cont Shelf Res 26(2):236-251. https://doi.org/10.1016/j.csr.2005.11.003

Omstedt A, Elken J, Lehmann A, Piechura J (2004) Knowledge of the Baltic Sea physics gained during the BALTEX and related programmes. Prog Oceanogr 63:1-28. https://doi.org/10.1016/j. pocean.2004.09.001

Omstedt A, Chen Y, Wesslander K (2005) A comparison between the ERA40 and the SMHI gridded meteorological databases as applied to Baltic Sea modelling. Nordic Hydrol 36(4):369-380

Omstedt A, Edman M, Anderson LG, Laudon H (2010) Factors influencing the acid-base $(\mathrm{pH})$ balance in the Baltic Sea: a sensitivity analysis. Tellus 62B:280-295. https://doi.org/10.1111 j.1600-0889.2010.00463.x

Omstedt A, Elken J, Lehmann A, Leppäranta M, Meier HEM, Myrberg K, Rutgersson A (2014) Progress in physical oceanography of the Baltic Sea during the 2003-2014 period. Prog Oceanogr 128:139171. https://doi.org/10.1016/j.pocean.2014.08.010

Onogi K, Tsutsui J, Koide H, Sakamoto M, Kobayashi S, Hatsushika $\mathrm{H}$, Matsumoto $\mathrm{T}$, Yamazaki N, Kamahori H, Takahashi K, 
Kadokura S, Wada K, Kato K, Oyama R, Ose T, Mannoji N, Taira R (2007) The JRA-25 reanalysis. J Meteorol Soc Jpn 85:369-432

Orlanski I (1976) A simple boundary condition for unbounded hyperbolic flows. J Comput Phys 21:251-269. https://doi.org/10.1016/ 0021-9991(76)90023-1

Piwowarczyk J, Hansson A, Hjerpe M, Chubarenko B, Karmanov $\mathrm{K}$ (2012) Climate change in the Baltic Sea region: a crosscountry analysis of institutional stakeholder perceptions. AMBIO 41(6):645-655

Pham TV, Brauch J, Dieterich C, Frueh B, Ahrens B (2014) New coupled atmosphere-ocean-ice system COSMO-CLM/NEMO: assessing air temperature sensitivity over the North and Baltic Seas. Oceanologia 56(2):167-189

Rienecker MM, Suarez MJ, Gelaro R, Todling R, Bacmeister J, Liu E, Bosilovich MG, Schubert SD, Takacs L, Kim G-K, Bloom S, Chen J, Collins D, Conaty A, daSilva A, Gu W, Joiner J, Koster RD, Lucchesi R, Molod A, Owens T, Pawson S, Pegion P, Redder CR, Reichle R, Robertson FR, Ruddick AG, Sienkiewicz M, Woollen J (2011) MERRA-NASA's modernera retrospective analysis for research and applications. J Clim. https://doi.org/10.1175/JCLI-D-11-00015

Rinke A, Gerdes R, Dethloff K, Kandlbinder T, Karcher M, Kauker F, Hiller S (2003) A case study of the anomalous Arctic sea ice conditions during 1990: insights from coupled and uncoupled regional climate model simulations. J Geophys Res 108(D9). https://doi.org/10.1029/2002JD003146

Rodi W (1980) Turbulence models and their application in hydraulicsa state-of-the-art review, report, 104 pp. International Association for Hydraulic Research, Delft

Rothrock DA (1975) The energetics of the plastic deformation of pack ice by ridging. J Geophys Res: Oceans 80(33):4514-4519

Rutgersson A, Nilsson EO, Kumar R (2012) Introducing surface waves in a coupled wave-atmosphere regional climate model: impact on atmospheric mixing length. J Geophys Res 117:C00J15. https://doi.org/10.1029/2012JC007940

Saha S, Moorthi S, Pan H-L, Wu X, Wang J, Nadiga S, Tripp P, Kistler R, Woollen J, Behringer D, Liu H, Stokes D, Grumbine R, Gayno G, Hou Y-T, Chuang H-Y, Juang H-MH, Sela J, Iredell M, Treadon R, Kleist D, Van Delst P, Keyser D, Derber J, Ek M, Meng J, Wei H, Yang R, Lord S, van den Dool H, Kumar A, Wang W, Long C, Chelliah M, Xue Y, Huang B, Schemm J-K, Ebisuzaki W, Lin R, Xie P, Chen M, Zhou S, Higgins W, Zou C-Z, Liu Q, Chen Y, Han Y, Cucurull L, Reynolds RW, Rutledge G, Goldberg M (2010) The NCEP climate forecast system reanalysis. Bull Am Meteorol Soc 91:1015-1057

Samuelsson P, Jones CG, Willén U, Ullerstig A, Gollvik S, Hansson U, Jansson C, Kjellström E, Nikulin G, Wyser K (2011) The Rossby centre regional climate model RCA3: model description and performance. Tellus A 63:4-23

Savchuk OP, Gustafson BG, Müller-Karulis B (2012) BALTSEM: a marine model for decision support within the Baltic Sea Region. BNI Technical Report 7. Baltic Nest Institute, Stockholm University, 59pp. ISBN 978-91-86655-06-8

Schrum C, Hubner U, Jacob D, Podzun R (2003) A coupled atmosphere/ice/ocean model for the North Sea and the Baltic Sea. Clim Dyn 21:131-151
Schubert SD, Rood R, Pfaendtner J (1993) An assimilated dataset for earth science applications. Bull Am Meteorol Soc 74:23312342

Seinä A, Kalliosaari S (1991) Jäätalvet 1986-90 Suomen merialueilla. Finn Mar Res 259:3-61

Seinä A, Palosuo E (1996) The classification of the maximum annual ice extent of ice cover in the Baltic Sea 1720-1995. Meri 27:79-91

Seinä A, Erönvall H, Kalliosaari S, Vainio J (1996) Ice seasons 1991-1995 in Finnish sea areas. Meri 27:3-77

Seinä A, Erönvall H, Kalliosaari S, Vainio J (2001) Ice seasons 1996-2000 in Finnish sea areas. Meri 43:3-98

Seinä A, Eriksson P, Kalliosaari S, Vainio J (2006) Ice seasons 2001-2005 in Finnish sea areas. Meri 57:3-77

Semtner AJ (1974a) A general circulation model for the World Ocean. UCLA Dept. of Meteorology Tech. Rep. No. 8, 99 pp

Semtner AJ (1974b) An oceanic general circulation model with bottom topography. Numerical Simulation of Weather and Climate 9. University of California, Los Angeles, p 99

Svensson U (1978) A mathematical model of the seasonal thermocline, Rep. 1002, 187 pp. Division of Water Resources Engineering University of Lund, Lund

Sommerfeld A (1949) Partial differential equations in physics. Academic Press, New York

Smith R, Gent P (2004) Reference manual for the parallel ocean program (POP). Los Alamos National Lab, New Mexico, p 75

Smith B, Samuelsson P, Wramneby A, Rummukainen M (2011) A model of the coupled dynamics of climate, vegetation and terrestrial ecosystem biogeochemistry for regional applications. Tellus A 63:87-106

Stroeve J, Holland MM, Meier W, Scambos T, Serreze M (2007) Arctic sea ice decline: faster than forecast, Geophys. Res Lett 34:L09501. https://doi.org/10.1029/2007GL029703

Tian T, Boberg F, Bössing Christenssen O, Hesselbjerg Christenssen J, She J, Vihma T (2013) Resolved complex coastlines and land sea contrasts in a high-resolution regional climate model: a comparative study using prescribed and modelled SSTs. Tellus A 19951. https://doi.org/10.3402/tellusa.v65i0.19951

Thorndike AS, Rothrock DA, Maykut GA, Colony R (1975) The thickness distribution of sea ice. J Geophys Res: Oceans 80(33):4501-4513. https://doi.org/10.1029/JC080i033p04501

Uppala SM, Kallberg PW, Simmons AJ, Andrae U, DaCostaBechtold V, Fiorino M, Gibson JK, Haseler J, Hernandez A, Kelly GA, Li X, Onogi K, Saarinen S, Sokka N, Allan RP, Andersson E, Arpe K, Balmaseda MA, Beljaars ACM, VanDeBerg L, Bidlot J, Bormann N, Caires S, Chevallier F, Dethof A, Dragosavac M, Fisher M, Fuentes M, Hagemann S, Hólm E, Hoskins BJ, Isaksen L, Janssen PAEM, Jenne R, McNally AP, Mahfouf JF, Morcrette J-J, Rayner NA, Saunders RW, Simon P, Sterl A, Trenberth KE, Untch A, Vasiljevic D, Viterbo P, Woollen J (2005) The ERA-40 re-analysis. Q J R Meteorol Soc 131:2961-3012

Williamson DL, Kiehl JT, Ramanathan V, Dickinson RE, Hack JJ (1987) Description of NCAR community climate model (CCM1). NCAR TECHNICAL NOTE

Yu L, Jin X, Weller RA (2007) Annual, seasonal, and interannual variability of air-sea heat fluxes in the Indian Ocean. J Clim 20(13):3190-3209. https://doi.org/10.1175/JCLI4163.1 